\title{
Primary Amine Functionalized N- Heterocyclic Carbene Complexes of Iridium: Synthesis, Structure, and Catalysis
}

\author{
Wylie W. N. O, Alan J. Lough, and Robert H. Morris
}

Version Post-print/accepted manuscript

Citation Wylie, W. N., Lough, A. J., \& Morris, R. H. (2013). Primary Amine

(published version) Functionalized N-Heterocyclic Carbene Complexes of Iridium:

Synthesis, Structure, and Catalysis. Organometallics, 32(14), 3808-3818.

DOI: $10.1021 / \mathrm{om} 400180 \mathrm{~h}$

Publisher's statement This document is the Accepted Manuscript version of a Published Work that appeared in final form in Organometallics, copyright (C) American Chemical Society after peer review and technical editing by the publisher. To access the final edited and published work see http://dx.doi.org/10.1021/om400180h

How to cite TSpace items

Always cite the published version, so the author(s) will receive recognition through services that track citation counts, e.g. Scopus. If you need to cite the page number of the author manuscript from TSpace because you cannot access the published version, then cite the TSpace version in addition to the published version using the permanent URI (handle) found on the record page.

This article was made openly accessible by $U$ of $T$ Faculty. Please tell us how this access benefits you. Your story matters. 


\title{
Primary Amine Functionalized N-Heterocyclic Carbene Complexes of Iridium: Synthesis, Structure and Catalysis
}

\author{
Wylie W. N. O, Alan J. Lough, and Robert H. Morris*
}

Davenport Laboratory, Department of Chemistry, University of Toronto, 80 St. George Street, Toronto, Ontario M5S 3H6, Canada.

*To whom correspondence should be addressed. E-mail: rmorris@ chem.utoronto.ca

\begin{abstract}
A square-planar iridium(I) complex $\left[\operatorname{Ir}(\operatorname{cod})\left(\mathrm{C}-\mathrm{NH}_{2}\right)\right] \mathrm{PF}_{6}(\mathbf{3} \cdot \mathbf{P F})$ containing a primary amine based $\mathrm{N}$ heterocyclic carbene ligand $\left(\mathrm{C}-\mathrm{NH}_{2}\right)$ ligand was synthesized by a transmetalation reaction of the nickel(II) complex 1, $\left[\mathrm{Ni}\left(\mathrm{C}-\mathrm{NH}_{2}\right)_{2}\right]\left(\mathrm{PF}_{6}\right)_{2}$, with $[\operatorname{Ir}(\operatorname{cod}) \mathrm{Cl}]_{2}(\operatorname{cod}=1,5$-cyclooctadiene $)$. An addition reaction of $\mathrm{HCl}$ with 3-PF $\mathbf{P}$ afforded a mixture of two isomers of the octahedral iridium(III) hydridochloride complex 5, $\mathrm{IrHCl}(\mathrm{cod})\left(\mathrm{C}-\mathrm{NH}_{2}\right) \mathrm{PF}_{6}$. One of the isomers, 5-cis-HCl, was found to have a rare geometry containing trans-H-Ir- $\mathrm{NH}_{2}$ and cis- $\mathrm{H}-\mathrm{Ir}-\mathrm{Cl}$ moieties. All of these iridium complexes were tested in the hydrogenation of unsaturated bonds. They are active catalysts in the $\mathrm{H}_{2}$-hydrogenation of acetophenone, with activity superior to a phosphine-amine $\left(\mathrm{P}-\mathrm{NH}_{2}\right)$ complex $\left[\operatorname{Ir}(\operatorname{cod})\left(\mathrm{P}-\mathrm{NH}_{2}\right)\right] \mathrm{PF}_{6} 4$, and half sandwich complexes $\left[\operatorname{Ir}\left(\mathrm{C}_{5} \mathrm{Me}_{5}\right)\left(\mathrm{C}-\mathrm{NH}_{2}\right) \mathrm{Cl}_{1} \mathrm{PF}_{6}(\mathbf{2 a})\right.$ and $\left[\operatorname{Ir}\left(\mathrm{C}_{5} \mathrm{H}_{5}\right)\left(\mathrm{C}-\mathrm{NH}_{2}\right) \mathrm{Cl}\right] \mathrm{PF}_{6}(\mathbf{2 b})$. Complex 3·PF6, however, was ineffective as a catalyst for the hydrogenation of trans- $\alpha$-methylstilbene and $N$-(1-phenylethylidene)aniline.
\end{abstract}

\section{Introduction}

Late-transition metal complexes containing donor-functionalized N-heterocyclic carbene (NHC) ligands have found diverse applications in homogeneous catalysis. ${ }^{1}$ Certain iridium NHC complexes were found to catalyze the hydrogenation of hindered alkenes ${ }^{2}$ and the Oppenauer-type oxidation of alcohols ${ }^{3}$ with exceptional turnover numbers (TON) and turnover frequencies (TOF). Key factors that explain the success of these catalysts include their robustness, the coordination versatility of the pendant donor group of the functionalized NHC ligand, and their structural features that favor metal-ligand co-operativity. ${ }^{1 \mathrm{a}, 1 \mathrm{c}}$

We began our studies in the use of an $\mathrm{N}$-heterocyclic carbene ligand $\left(\mathrm{C}-\mathrm{NH}_{2}\right)$ with a tethered primary amine group in late-transition metal bifunctional catalysts for the hydrogenation of polar double bonds, which utilizes the co-operative action of the $\mathrm{M}-\mathrm{H}$ and the $\mathrm{N}-\mathrm{H}$ groups. ${ }^{4}$ In transmetalation reactions, nickel(II) complex 1, ${ }^{5}\left[\mathrm{Ni}\left(\mathrm{C}-\mathrm{NH}_{2}\right)_{2}\right]\left(\mathrm{PF}_{6}\right)_{2}$, transfers its $\mathrm{C}-\mathrm{NH}_{2}$ ligand to half sandwich ruthenium(II) ${ }^{5-6}$ and iridium(III) complexes $\mathbf{2 a}, \mathbf{2 b}$ and $\mathbf{2 c}$ (Figure 1$){ }^{7}$ giving active catalysts for the hydrogenation of ketones and esters with high turnover numbers and turnover frequencies. ${ }^{6 a, 8}$ Our studies of the action of the iridium(III) catalyst 2a suggested that catalysis proceeds via a neutral iridium(I) hydride-amine complex in an alcohol-assisted bifunctional mechanism (Scheme 1). ${ }^{7}$ On the other hand, the cationic hydride-amine complex 2c does not react with a ketone in a stoichiometric reaction in the absence of an alkoxide base. We attributed the poor reactivity of such cationic hydride complexes to the diminished nucleophilicity of the hydride ligand towards the electrophilic carbonyl group of a ketone. ${ }^{6 b, 7}$ Cross and co-workers reported the catalytic hydrogenation of ketones by hydrogen transfer from isopropanol at reflux using the amido complex $\mathbf{2 d}$ in the presence of an alkoxide base; ${ }^{9 \mathrm{a}}$ rates were slow compared to the complexes described in the present work. Iridium cyclooctadiene complexes containing an unfunctionalized NHC ligand also are active as transfer hydrogenation catalysts. ${ }^{9 \mathrm{~b}, \mathrm{c}}$ 


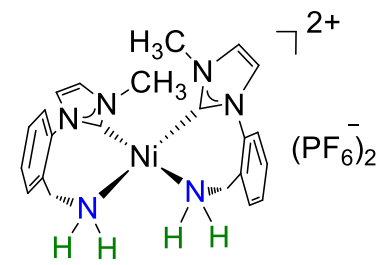

1

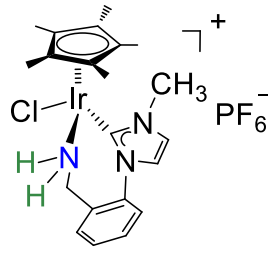

$2 \mathrm{a}$

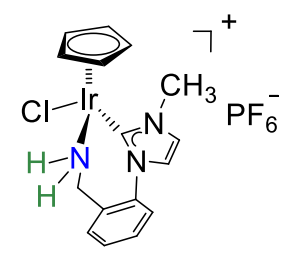

2b

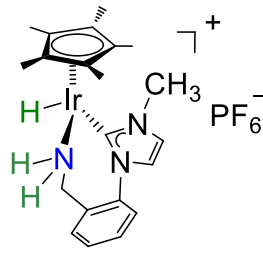

2c

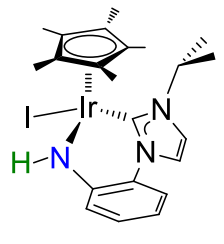

2d

Figure 1. Nickel(II) and iridium(III) complexes containing an N-heterocyclic carbene-amine $\left(\mathrm{C}-\mathrm{NH}_{2}\right)$ ligand.

\section{Scheme 1. An Alcohol-assisted Bifunctional Mechanism in Ketone Hydrogenation Involving a Neutral Iridium(I) Hydride-Amine Complex}

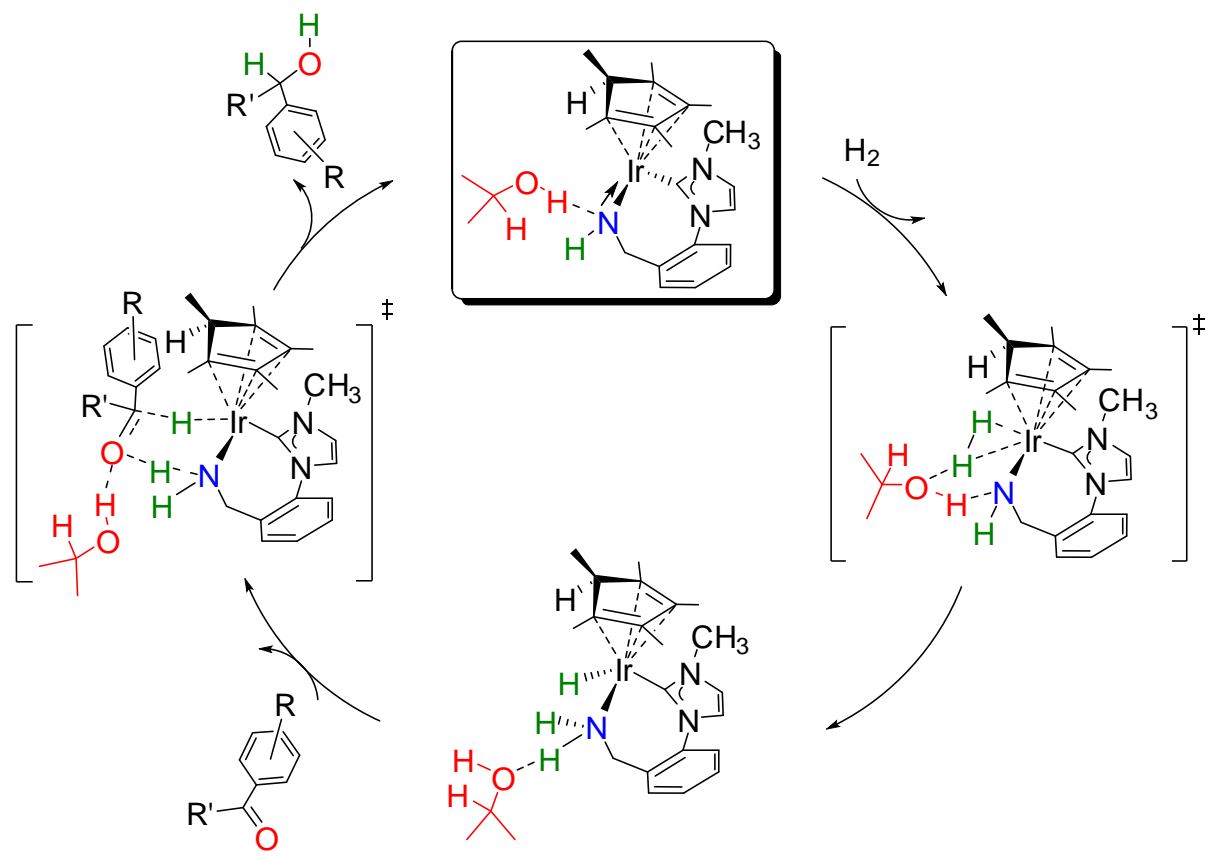

There are few examples of iridium catalysts that contain a chelating phosphine-amine (P-NHR) ligand reported for the hydrogenation of ketones using 2-propanol or hydrogen as the hydrogen source (Figure 2). ${ }^{10}$ We believed that the replacement of the phosphine donor in the P-NHR ligand on iridium by an NHC donor could lead to more active catalysts for ketone hydrogenation using hydrogen gas. In fact, this has been achieved for iridium catalysts containing a tethered oxazoline donor for stereoselective hindered alkene hydrogenation (Figure 2). ${ }^{2}$ Here we report our studies into the synthesis and reactivity of iridium(I) complexes containing a $\mathrm{C}-\mathrm{NH}_{2}$ ligand. The first structure of an octahedral complex of iridium(III) containing a $\mathrm{Ir}-\mathrm{H}$ and $\mathrm{N}-\mathrm{H}$ group with such a chelating ligand is also described here. Of particular interest is the catalytic activity of all of these complexes for ketone and hindered alkene hydrogenation.

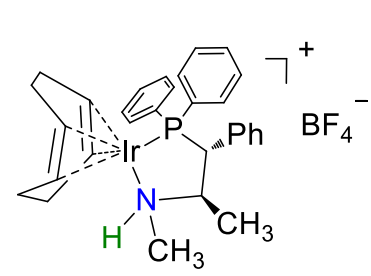

Ketone Hydrogenation Catalysts

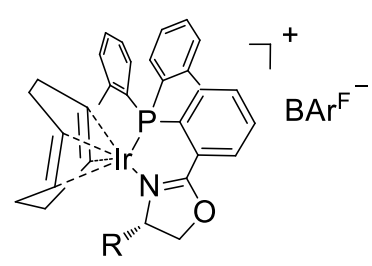

$\mathrm{R}={ }^{i} \operatorname{Pr} \mathrm{OR}^{t} \mathrm{Bu}$

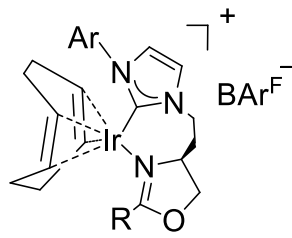

$\mathrm{Ar}=2,6-\left({ }^{i} \mathrm{Pr}\right)_{2} \mathrm{C}_{6} \mathrm{H}_{3}$ $\mathrm{R}=\mathrm{Ph} \mathrm{OR}^{\mathrm{t}} \mathrm{Bu}$

Hindered Alkene Hydrogenation Catalysts 
Figure 2. Iridium catalysts for the hydrogenation of ketones and hindered alkenes that contain a chelating phosphine-amine (P-NHR) or a functionalized-NHC ligand.

\section{Results and Discussion}

Synthesis of iridium(I) complexes 3 and 4. The iridium(I) complex containing the $\mathrm{C}-\mathrm{NH}_{2}$ ligand, [ $\operatorname{Ir}(\mathrm{C}-$ $\left.\mathrm{NH}_{2}\right)$ (cod) $\mathrm{PF}_{6}(\mathbf{3} \cdot \mathbf{P F}$ ), was synthesized by a transmetalation reaction of the nickel(II) complex 1 with $[\operatorname{Ir}(\operatorname{cod}) \mathrm{Cl}]_{2}$ in refluxing acetonitrile solution. ${ }^{5}$ The subsequent work-up in dichloromethane $\left(\mathrm{CH}_{2} \mathrm{Cl}_{2}\right)$ afforded the title complex in $70 \%$ yield as a yellow powder (Scheme 2). The solid state structure of 3. $\mathrm{PF}_{6} \cdot \mathbf{0 . 5 C H}_{2} \mathrm{Cl}_{2}$ shows a square planar geometry about the iridium(I) center with coordinated 1,5cyclooctadiene (cod) and the $\mathrm{C}-\mathrm{NH}_{2}$ ligands (Figure 3). The $\mathrm{Ir}-\mathrm{C}(\mathrm{cod})$ bond distance measured from the centroid of the olefin that is trans to the NHC donor $(\operatorname{Ir}(1 \mathrm{a})-\operatorname{cod}(\operatorname{trans}$ to $\mathrm{C})$ cent, $2.068 \AA)$ is longer than the one trans to the amine donor $\left(\operatorname{Ir}(1 \mathrm{a})-\operatorname{cod}(\operatorname{cis} \text { to } \mathrm{C})_{\text {cent }}=1.984 \AA\right)$ as a result of a stronger trans influence of the carbene compared to an amine group, as expected. ${ }^{11}$ The $\operatorname{Ir}-\mathrm{C}$ (carbene) distance of $\mathbf{3} \cdot \mathbf{P F}_{\mathbf{6}}(\operatorname{Ir}(1 \mathrm{a})-$ $\mathrm{C}(1 \mathrm{a})=2.048(9) \AA)$ is in the expected range. ${ }^{12}$ In dichloromethane- $d_{2}$ solution, the carbene carbon (Ir-

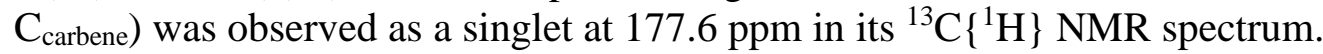

We also prepared an analogous complex with a tetrakis[3,5-bis(trifluoromethyl)phenyl]borate $\left(\mathrm{BAr} \mathrm{r}^{\mathrm{F}}\right)$ ion 3. $\mathbf{B A r}{ }^{\mathbf{F}}$ by counter-anion metathesis of 3. $\mathbf{P F} 6$ with $\mathrm{NaBAr}^{\mathrm{F}}$ in $\mathrm{CH}_{2} \mathrm{Cl}_{2}$ (Scheme 2). The identity of the complex was established by the presence of a singlet at $-62.9 \mathrm{ppm}$ (for the $\mathrm{BAr}^{\mathrm{F}}$ anion) and the absence of a doublet at $-72.6 \mathrm{ppm}$ (for $\mathrm{PF}_{6}$ anion) in its ${ }^{19} \mathrm{~F}$ NMR spectrum recorded in dichloromethane- $d_{2}$. Of note, the very weak coordination of the $\mathrm{BAr}^{\mathrm{F}}$ anion to metal ions makes it ideal for use as the counterion in iridium(I) complexes for the efficient hydrogenation of hindered alkenes. ${ }^{11 \mathrm{~b}, 13}$

\section{Scheme 2. Synthesis of Iridium Complexes 3 and 5 Containing a $\mathrm{C}-\mathrm{NH}_{2}$ Ligand}
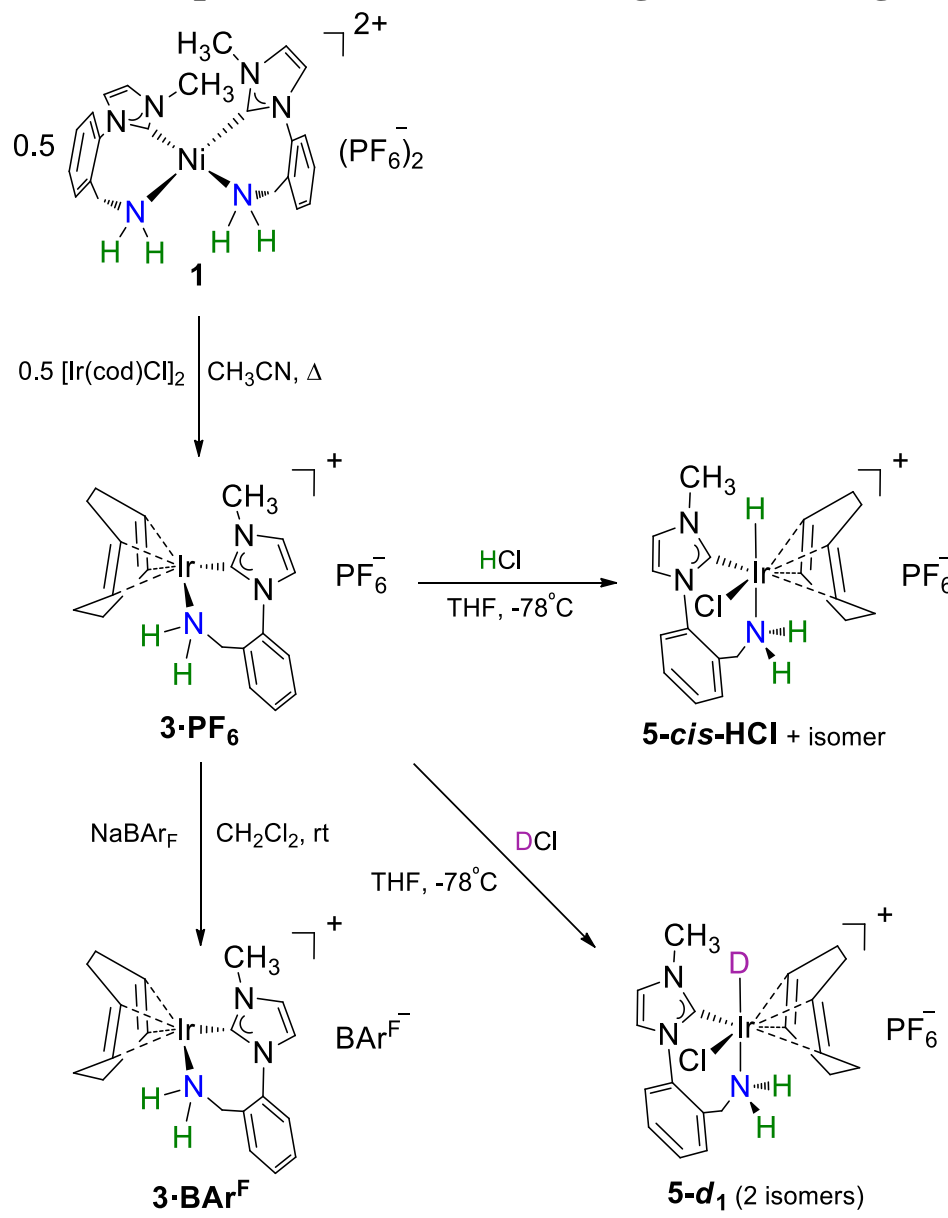
For comparison, we synthesized a phosphine-amine complex of iridium(I), $\left[\operatorname{Ir}\left(\mathrm{P}-\mathrm{NH}_{2}\right)(\operatorname{cod})\right] \mathrm{PF}_{6}(4)$, by a reaction of 2-(diphenylphosphino)benzylamine $\left(\mathrm{P}-\mathrm{NH}_{2}\right)^{14}$ and $[\operatorname{Ir}(\operatorname{cod}) \mathrm{Cl}]_{2}$ in the presence of a stoichiometric amount of $\mathrm{AgPF}_{6}$ in a mixture of $\mathrm{CH}_{2} \mathrm{Cl}_{2}$ and acetonitrile $\left(\mathrm{CH}_{3} \mathrm{CN}\right)$ solution (in 6:1 ratio, Scheme 3). This was also characterized by ${ }^{1} \mathrm{H},{ }^{13} \mathrm{C}\left\{{ }^{1} \mathrm{H}\right\}$ and ${ }^{31} \mathrm{P}\left\{{ }^{1} \mathrm{H}\right\}$ NMR spectroscopies and an X-ray diffraction study (Figure 4). The spectral data of $\mathbf{4}$ is similar to analogous complexes reported in the literature. $^{10 \mathrm{a}}$

\section{Scheme 3. Synthesis of 4 Containing a 2-(Diphenylphosphino)benzylamine Ligand}
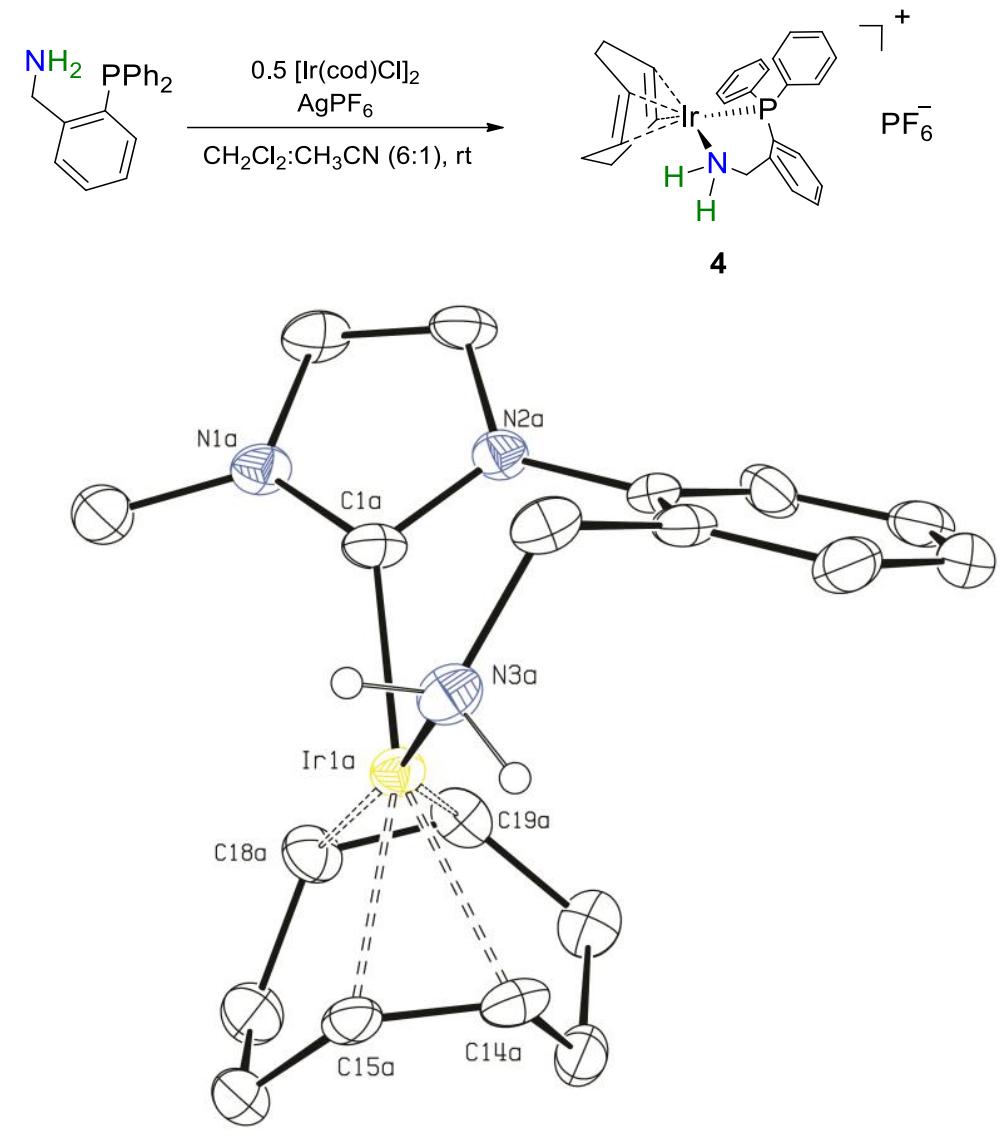

Figure 3. ORTEP representation of $3 \cdot \mathbf{P F}_{6} \cdot \mathbf{0 . 5 C H}_{2} \mathbf{C l}_{2}$ depicted with thermal ellipsoids at $30 \%$ probability. The counteranion, solvent molecule, and most of the hydrogens have been omitted for clarity. Only one asymmetric unit is shown. Selected bond distances $(\AA)$ and bond angles (deg): $\operatorname{Ir}(1 \mathrm{a})-\mathrm{C}(1 \mathrm{a}), 2.048(9)$; $\operatorname{Ir}(1 \mathrm{a})-\mathrm{N}(3 \mathrm{a}), 2.108(8) ; \operatorname{Ir}(1 \mathrm{a})-\operatorname{cod}(\text { trans to } \mathrm{C})_{\text {cent }}, 2.068 ; \operatorname{Ir}(1 \mathrm{a})-\operatorname{cod}(\text { cis to } \mathrm{C})_{\text {cent }}, 1.984 ; \mathrm{C}(14 \mathrm{a})-\mathrm{C}(15 \mathrm{a})$, 1.39(1); C(18a)-C(19a), 1.40(2); C(1a)-Ir(1a)-N(3a), 90.0(4); C(1a)-Ir(1a)-cod(trans to C)avg, 161.4; $\mathrm{N}(3 \mathrm{a})-\operatorname{Ir}(1 \mathrm{a})-\operatorname{cod}($ cis to $\mathrm{C})$ avg, 160.4 . 


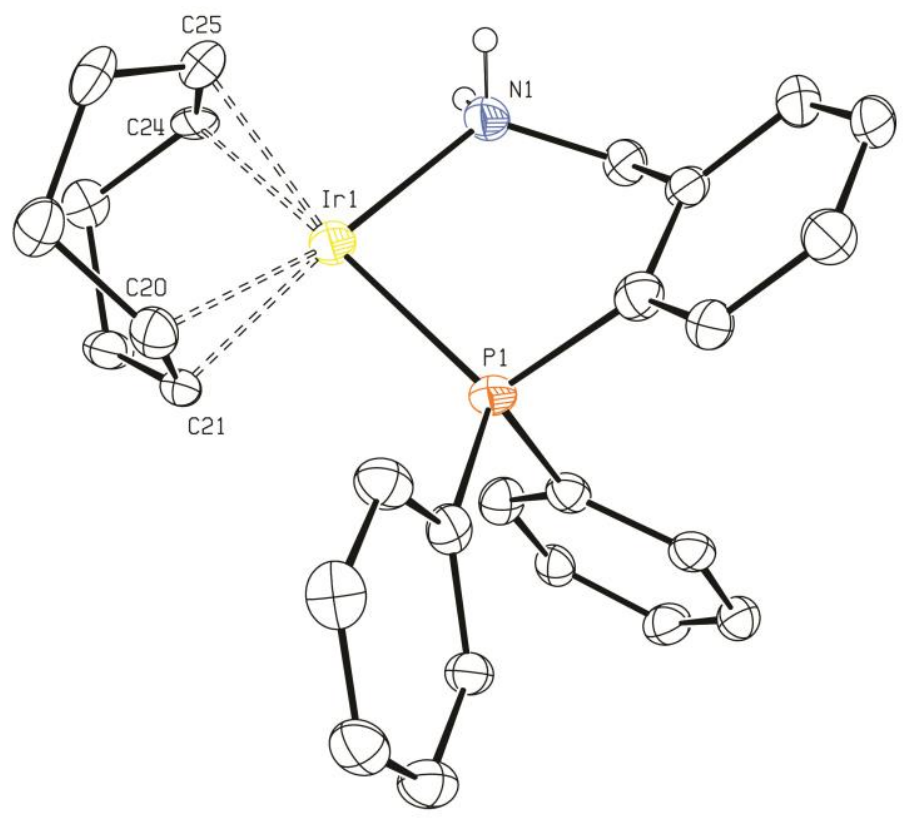

Figure 4. ORTEP representation of $\mathbf{4}$ depicted with thermal ellipsoids at $30 \%$ probability. The counteranion and most of the hydrogens have been omitted for clarity. Selected bond distances $(\AA)$ and bond angles (deg): $\operatorname{Ir}(1)-\mathrm{P}(1), 2.307(2) ; \operatorname{Ir}(1)-\mathrm{N}(1), 2.123(6) ; \operatorname{Ir}(1)-\operatorname{cod}(\operatorname{trans} \text { to } \mathrm{P})_{\text {cent }}, 2.085 ; \operatorname{Ir}(1)-$ cod(cis to P) cent, 2.027; C(20)-C(21), 1.40(1); C(24)-C(25), 1.39(1); P(1)-Ir(1)-N(1), 89.6(2); P(1)$\operatorname{Ir}(1)-\operatorname{cod}(\text { trans to } \mathrm{P})_{\mathrm{avg}}, 161.5 ; \mathrm{N}(1)-\operatorname{Ir}(1)-\operatorname{cod}(\operatorname{cis} \text { to } \mathrm{P})_{\mathrm{avg}}, 160.0$.

Addition of hydrogen chloride to the iridium(I) complex 3·PF6. We further explored the reactivity of the iridium(I) complex 3.PF $\mathbf{P}$ containing the $\mathrm{C}-\mathrm{NH}_{2}$ ligand. The addition of an excess of hydrochloric acid $(\mathrm{HCl})$ in diethyl ether to a solution of $\mathbf{3} \cdot \mathbf{P F} 6$ in tetrahydrofuran $(\mathrm{THF})$ at $25^{\circ} \mathrm{C}$ afforded two isomers containing an iridium hydride, as identified by ${ }^{1} \mathrm{H}$ and ${ }^{13} \mathrm{C}$ NMR spectroscopy. The characteristic $\mathrm{Ir}-\mathrm{H}$ resonances of the product mixture in THF- $d_{8}$ were observed at -12.48 and $-14.61 \mathrm{ppm}$. The optimum reaction condition ${ }^{15}$ was the slow addition of exactly 1 equiv of $\mathrm{HCl}(0.01 \mathrm{M})$ to a dilute solution $(2-3$ $\mathrm{mM}$ ) of $\mathbf{3} \cdot \mathbf{P F} 6$ in $\mathrm{THF}$ at $-78^{\circ} \mathrm{C}$. This gave over $90 \%$ of the iridium(III) hydridochloride complex, $\left[\operatorname{IrHCl}\left(\mathrm{C}-\mathrm{NH}_{2}\right)(\mathrm{cod})\right] \mathrm{PF}_{6}(5)$, containing a major hydride peak at $-14.61 \mathrm{ppm}$ in THF- $d_{8}$ upon isolation from the reaction mixture (Scheme 2). We have also attempted to prepare the same complex by a transmetalation reaction of [ $\left.\mathrm{IrHCl}_{2} \mathrm{Cod}\right]_{2}{ }^{16}$ with 1 equiv. of nickel(II) complex 1 in refluxing acetonitrile solution. This, however, gave an approximately equal amount of the two isomers upon isolation of the product (see the experimental section).

Interestingly, the major isomer of the hydridochloride complex 5 slowly isomerizes at $25^{\circ} \mathrm{C}$ (up to 5 days) to the other isomer, resulting in about 1 to 1 ratio in acetonitrile- $d_{3}$, THF- $d_{8}$ or dichloromethane- $d_{2}$ solutions. The isomerization reaction can be sped up to within $24 \mathrm{~h}$ by heating the solution at $40^{\circ} \mathrm{C}$ under an argon atmosphere, giving the same ratio of the two isomers, as identified by ${ }^{1} \mathrm{H} \mathrm{NMR}$. Heating such sample longer did not affect the relative ratios of the two isomers in solution.

We have also prepared the deuteride complex $\mathbf{5}-\boldsymbol{d}_{\mathbf{1}}$ by the reaction of $\mathrm{DCl}\left(97.5 \%\right.$ atom D) with $\mathbf{3} \cdot \mathbf{P F}_{\mathbf{6}}$ using the same reaction conditions as with the preparation of 5 (Scheme 2). Partial deuteration ( 60 $70 \%$ ) of the hydride ligand in the major isomer was observed in THF- $d_{8}$ by ${ }^{1} \mathrm{H}$ NMR. Isomerization of the major isomer and H/D exchange of the deuteride ligand occur upon heating the NMR sample at $40^{\circ} \mathrm{C}$ under argon. This gave about 1 to 1 ratio of the isomers, judging from the integration ratio of the hydride peaks in its ${ }^{1} \mathrm{H}$ NMR spectrum, and about $50 \%$ of the hydride ligands of both isomers were partially deuterated. 
Slow diffusion of diethyl ether into a saturated solution of $\mathbf{5}$ in THF afforded single crystals of 5-cis-HCl (Figure 5). The octahedral complex contains a hydride ligand that is trans to the amine group of the C$\mathrm{NH}_{2}$ ligand. The carbene, amine, and hydride donors are coordinated to the iridium center in a meridional fashion. The hydride position of 5-cis-HCl was located and refined during structural determination; the Ir-H distance was thus determined to be 1.64(6) $\AA$. This is longer than those of the few octahedral complexes containing an $\mathrm{IrH}(\mathrm{NHC})^{2+}$ motif $^{17}$ where the hydride ligand was located in the solid state structure. There are other well-defined structures obtained by $\mathrm{C}-\mathrm{H}$ bond activation of the NHC ligand, ${ }^{18}$ or oxidative addition of a $\mathrm{H}-\mathrm{X}$ group,${ }^{19}$ yet the hydride position was not located. The carbene ligand has a stronger trans influence compared to a chloride ligand, judging from the $\mathrm{Ir}-\mathrm{C}(\mathrm{cod})$ bond distance measured from the centroid of the olefin that is trans to the donor ligand, as expected ( $\operatorname{Ir}(1)-\operatorname{cod}(\operatorname{trans}$ to C) cent, $\left.2.159 \AA, \operatorname{Ir}(1 \mathrm{a})-\operatorname{cod}(\text { cis to } \mathrm{C})_{\text {cent }}=2.066 \AA\right)$. Attempts to obtain spectroscopic data from the single crystals by NMR were not successful, as a one to one ratio of the isomers was always observed in various NMR solvents upon dissolution of the crystals.

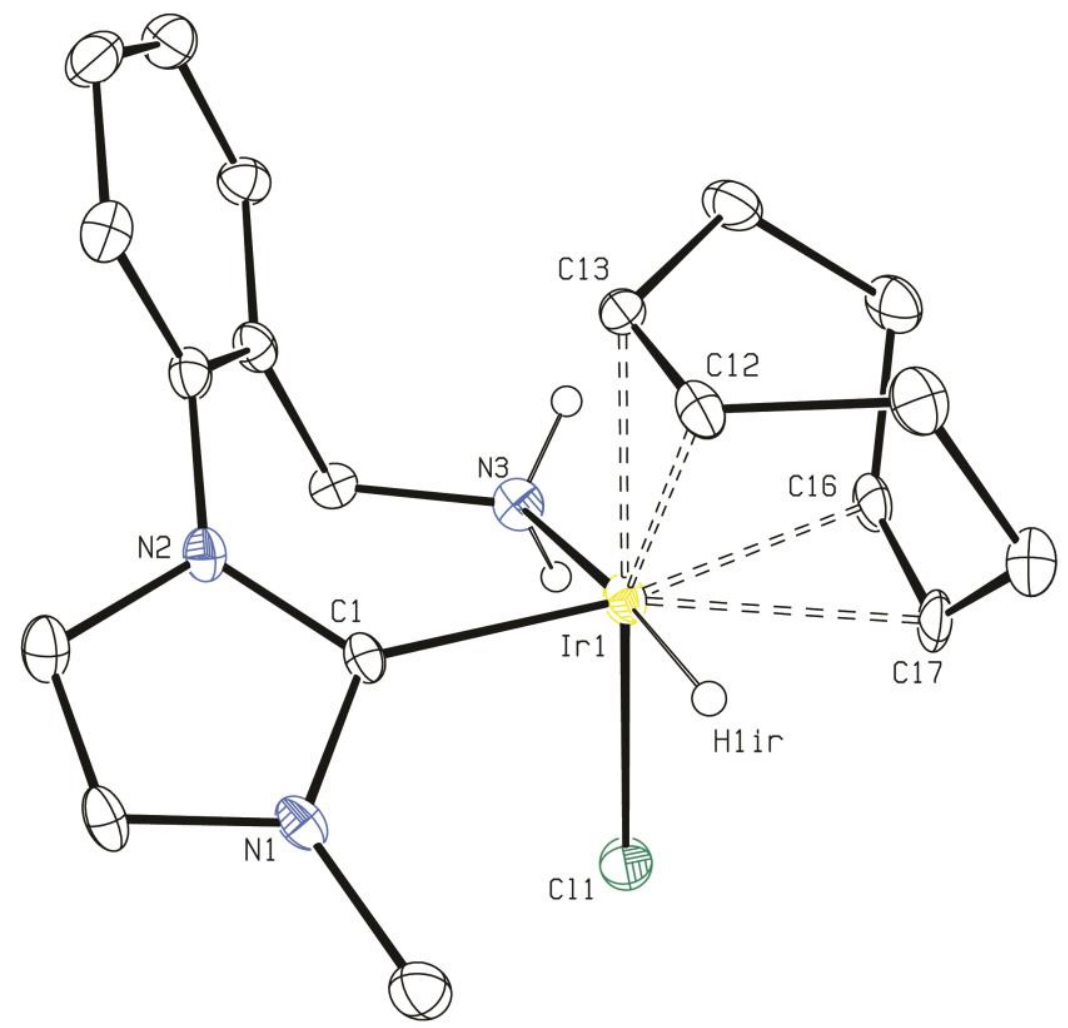

Figure 5. ORTEP representation of 5-cis-HCI depicted with thermal ellipsoids at 30\% probability. The counteranion and most of the hydrogens have been omitted for clarity. Selected bond distances $(\AA)$ and bond angles (deg): $\operatorname{Ir}(1)-\mathrm{C}(1), 2.053(5) ; \operatorname{Ir}(1)-\mathrm{N}(3), 2.218(4) ; \operatorname{Ir}(1)-\mathrm{H}(1 \mathrm{ir}), 1.64(6) ; \operatorname{Ir}(1)-\mathrm{Cl}(1), 2.403(2)$; $\operatorname{Ir}(1)-\operatorname{cod}(\operatorname{trans} \text { to } \mathrm{C})_{\text {cent }}, 2.159 ; \operatorname{Ir}(1)-\operatorname{cod}(\operatorname{cis} \text { to } \mathrm{C})_{\text {cent, }}$ 2.066; $\mathrm{C}(12)-\mathrm{C}(13), 1.403(8) ; \mathrm{C}(16)-\mathrm{C}(17)$, 1.388(9); C(1)-Ir(1)-N(3), 92.0(2); N(3)-Ir(1)-H(1ir), 175(2); C(1)-Ir(1)-cod(trans to C) avg, 162.1; $\mathrm{Cl}(1)-\operatorname{Ir}(1)-\operatorname{cod}($ cis to $\mathrm{C})$ avg, 160.3 .

Octahedral complexes like 5-cis-HCl containing a trans-H-M- $\mathrm{NH}_{2}$ group $\left(\mathrm{M}=\mathrm{Ru}\right.$, Ir) are rare. ${ }^{20}$ There $^{2}$ are six possible isomers of the hydridochloride complex 5 that can be produced by the addition of $\mathrm{HCl}$ to complex 3.PF $\mathbf{6}$ (Figure 6); these are dependent on the relative positions of the hydride and the chloride ligands. We therefore used density functional theory (DFT) calculations to compare the relative energies of all of these isomers. 

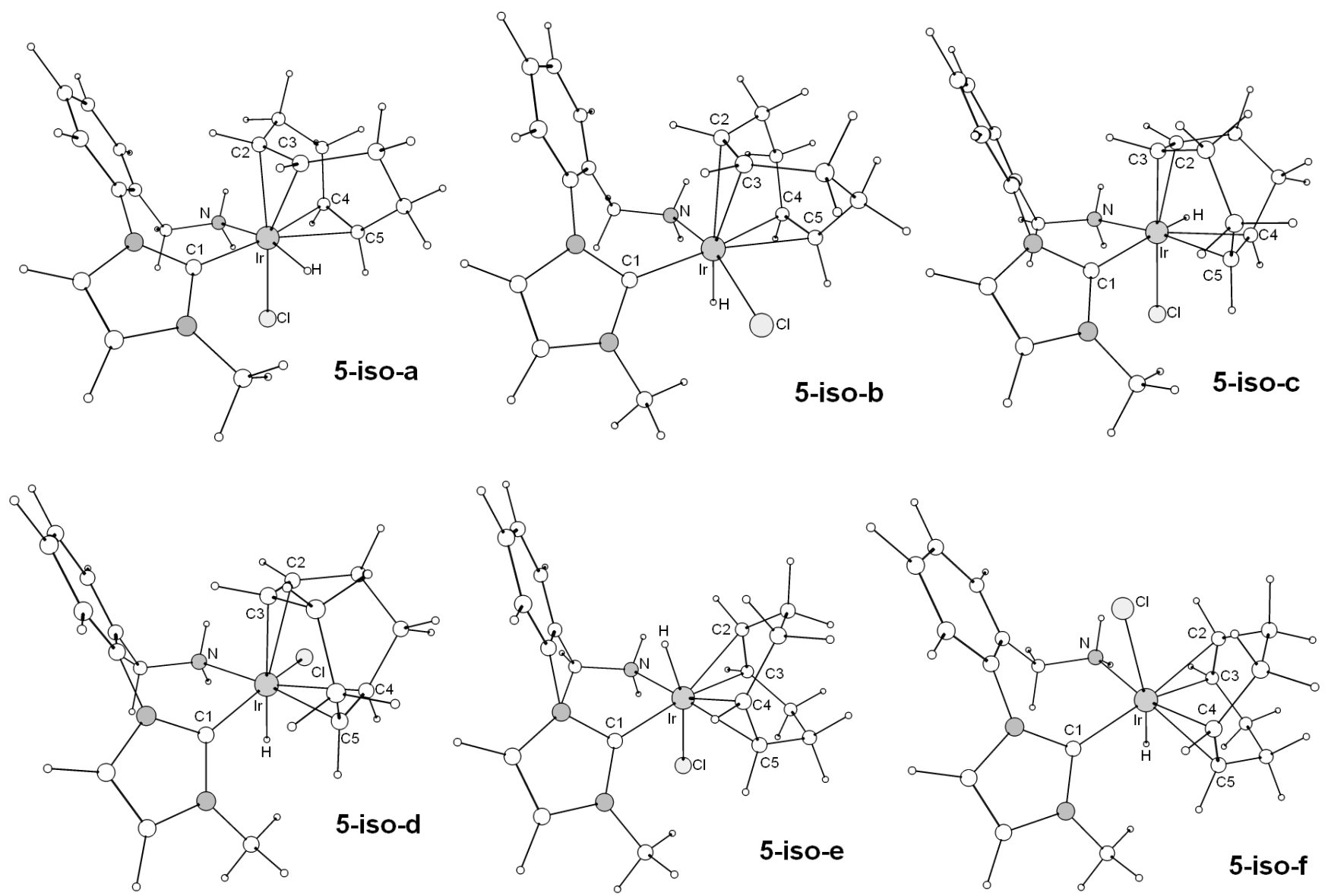

Figure 6. Computed structures for the possible isomers of iridium(III) hydridochloride complexes 5-isoa to 5-iso-f in the gas phase (1 atm, $298 \mathrm{~K})$. Selected calculated bond lengths ( $⿱$ ) $)$ and bond angles (deg) are given in Table $\mathrm{S} 1$ in Supporting Information.

Our studies used the restricted hybrid mPW1PW9 $1^{21}$ functional where iridium was treated with the SDD 22 relativistic effect core potential (ECP) and an associated basis set. They show that the computed structure 5-iso-e has a similar free energy and enthalpy (within $0.2 \mathrm{kcal} / \mathrm{mol}$ difference) to 5-iso-a (5-cis-HCl) (see Table 1). The structure of 5-iso-e has cis-H-Ir- $\mathrm{NH}_{2}$ and trans- $\mathrm{H}-\mathrm{Ir}-\mathrm{Cl}$ groupings. Calculations using the M06 $^{23}$ functional where iridium was treated with the SDD relativistic ECP and an associated basis set gave a similar trend in energies, within the error of the methods (Table 1). It is worth pointing out that an isomer containing a trans- $\mathrm{H}-\mathrm{Ir}-\mathrm{Cl}$ group was often obtained as the major product in the addition reaction of hydrogen halides to square-planar iridium(I) complexes with phosphines and diene ligands. ${ }^{24}$ The geometric parameters of the computed structure 5-iso-a are very similar to those of 5-cis-HCl for the range of functionals that were used (see Tables S1 and S2 in the Supporting Information). 
Table 1. Relative Energies of the Isomers of the Iridium(III) Hydridochloride Complexes 5-iso-a to 5-iso-f

\begin{tabular}{ccccccc}
$\begin{array}{c}\text { Relative Energy } \\
(\mathrm{kcal} / \mathrm{mol}) / \text { Functional }\end{array}$ & 5-iso-a & 5-iso-b & 5-iso-c & 5-iso-d & 5-iso-e & 5-iso-f \\
\hline$\Delta \mathrm{G}(\mathrm{mPW} 1 \mathrm{PW} 91)^{\mathrm{a}}$ & 0.0 & 21.0 & 12.2 & 15.7 & -0.19 & 10.8 \\
\hline$\Delta \mathrm{G}(\mathrm{M} 06)$ & 0.0 & 19.0 & 11.9 & 14.2 & 1.64 & 10.7 \\
\hline$\Delta \mathrm{H}(\mathrm{mPW} 1 \mathrm{PW} 91)^{\mathrm{b}}$ & 0.0 & 21.1 & 12.0 & 16.2 & -0.15 & 10.6 \\
\hline$\Delta \mathrm{H}(\mathrm{M} 06)$ & 0.0 & 19.1 & 11.3 & 14.4 & 1.55 & 10.4
\end{tabular}

${ }^{\mathrm{a}} \Delta \mathrm{G}=$ Free energy relative to 5-iso-a. ${ }^{\mathrm{b}} \Delta \mathrm{H}=$ Enthaply relative to 5-iso-a.

Our computational studies provide evidence for the identities of the two isomers that were observed in the addition reaction of $\mathrm{HCl}$ to complex 3.PF6. It has been proposed that the addition of $\mathrm{HX}(\mathrm{X}=\mathrm{halides})$ to square-planar iridium(I) complex containing phosphine ligands proceed by an ionic mechanism: the halide anion first attacks the metal center, follow by protonation of a five-coordinate intermediate. ${ }^{24}$ If the addition of chloride anion and a proton to complex 3.PF6 were to occur in a $\mathrm{cis}$-fashion, ${ }^{24 \mathrm{c},}{ }^{25}$ this would give complexes 5-cis-HCl and its isomer 5-cis-iso-HCl. These correspond to the computed structures 5iso-a and 5-iso-b, respectively. The formation of 5-cis-iso-HCl is unfavourable based on thermodynamic grounds, as evident from our calculations (Table 1). Complex 5-cis-HCl, on the other hand, can slowly isomerize to 5-trans-HCl (Scheme 4). This corresponds to the model complex 5-iso-e. As the computed structures 5-iso-a and 5-iso-e representing 5-cis-HCl and 5-trans-HCl are very similar in free energies and enthalpies, it appears the two complexes can co-exist in solution. The spectroscopic data obtained for the product mixture from the addition reaction, however, are insufficient to assign the proper identities of the two isomers.

Scheme 4 Proposed Reaction Pathway for the Formation of Complex 5 in Solution
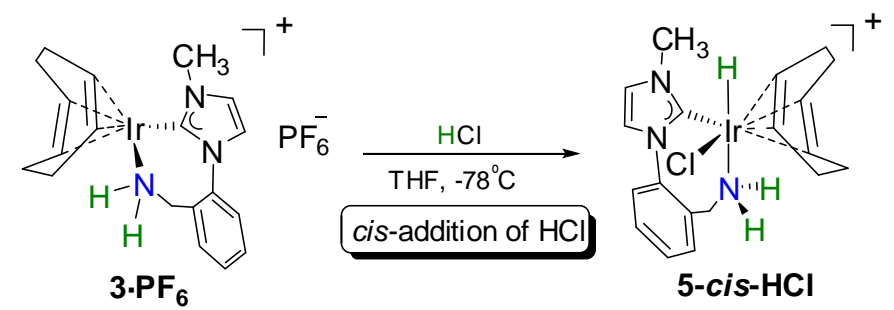

Structurally characterized

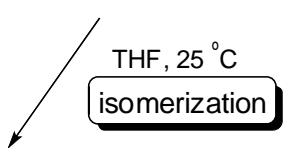

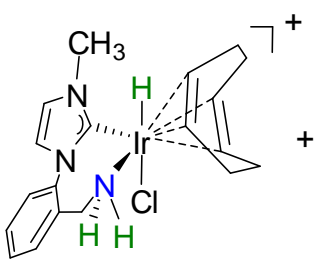

5-trans-HC

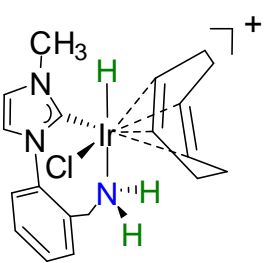

$5-$ cis- $\mathrm{HCl}$

1:1 ratio

Iridium catalyzed hydrogenation of substrates with unsaturated bonds. The iridium complexes $\mathbf{3}, 4$ and 5 were tested for the hydrogenation of acetophenone, trans- $\alpha$-methylstilbene and $N$-(1-phenylethylidene)aniline (Table 2). Complex 3.PF6 catalyzed the hydrogenation of acetophenone to full 
conversion in 10 min under 25 bar of $\mathrm{H}_{2}$ pressure at $50^{\circ} \mathrm{C}$ in THF in the presence of potassium tertbutoxide $\left(\mathrm{KO}^{t} \mathrm{Bu}\right)$ as the base, with a catalyst to substrate $(\mathrm{C} / \mathrm{S})$ ratio of $1 / 200$ (entry 1$)$. This has activity superior to complexes $\mathbf{2 a}$ and $\mathbf{2 b}$ under similar reaction conditions, ${ }^{7}$ and better than that of the phosphineamine complex $4\left(\mathrm{TOF}=144 \mathrm{~h}^{-1}\right.$, entry 5). At a lower hydrogenation pressure and temperature with $\mathbf{3} \cdot \mathbf{P F}$, full conversion was achieved in $1 \mathrm{~h}$ with a TOF value of $543 \mathrm{~h}^{-1}$ (entry 2). When reactions were carried out at a higher substrate loading $(\mathrm{C} / \mathrm{S}=1 / 1500)$ and at different temperatures $\left(25\right.$ or $\left.50^{\circ} \mathrm{C}\right)$, the reaction profile plateaus at about $50 \%$ conversion of acetophenone to the product alcohol (entries 3 and 4 ). It is known that the formation of enolate ions slows down catalysis by competing with the coordination of $\mathrm{H}_{2}$ to the metal center in the rate-determining step. ${ }^{6 \mathrm{~b}, 7,26}$ It appears that the high concentration of enolate ions that are formed in these reaction conditions irreversibly depleted the active species that are responsible for catalysis.

The hydride-amine complex 5, which contains a bifunctional $\mathrm{Ir}-\mathrm{H} / \mathrm{N}-\mathrm{H}$ pair, was tested for the hydrogenation of acetophenone as well. The catalyst was inactive in the absence of $\mathrm{KO}^{t} \mathrm{Bu}$ for the hydrogenation of acetophenone (entry 6). The presence of a poor trans influence ligand (amine or a chloride) that is trans to the hydride ligand most likely accounts for the inactivity that was observed. ${ }^{4 a}$ In the presence of 8 equiv of the alkoxide base, on the other hand, complex 5 catalyzed the hydrogenation of acetophenone to 1-phenylethanol in 30 min under 25 bar of $\mathrm{H}_{2}$ and at $50^{\circ} \mathrm{C}$ in THF. At a lower $\mathrm{H}_{2}$ pressure ( 8 bar), full conversion was achieved in $1 \mathrm{~h}$ with a TOF value of $825 \mathrm{~h}^{-1}$ (entries 7 and 8). Of note, this system has activity higher than those of complexes $\mathbf{2 a}, \mathbf{2 b}$ and $\mathbf{4}$ and some other iridium phosphine-amine complexes reported in the literature for the $\mathrm{H}_{2}$-hydrogenation of acetophenone, ${ }^{10 \mathrm{a}, 10 \mathrm{e}, 27}$ and it has activity comparable to the pincer complex $\operatorname{IrH}_{2} \mathrm{Cl}\left[\left({ }^{i} \mathrm{Pr}_{2} \mathrm{PCH}_{2} \mathrm{CH}_{2}\right)_{2} \mathrm{NH}\right]$ when activated by $\mathrm{KO}^{t} \mathrm{Bu}^{10 \mathrm{f}}$

Table 2. Iridium Catalyzed Hydrogenation of Substrates with Unsaturated Bonds

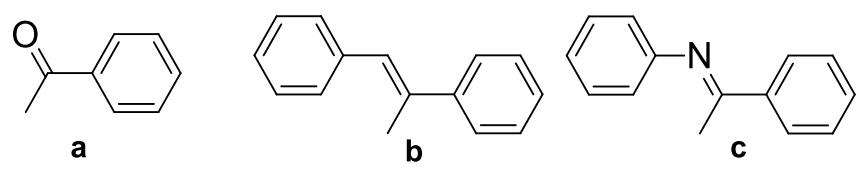

\begin{tabular}{|c|c|c|c|c|c|c|c|c|c|}
\hline Entry $^{a}$ & $\begin{array}{c}\text { Catalyst } \\
\text { (C) }\end{array}$ & $\begin{array}{c}\text { Substrate } \\
(\mathrm{S})\end{array}$ & $\begin{array}{c}\mathrm{P}\left(\mathrm{H}_{2}\right) / \\
\text { bar }\end{array}$ & Solvent & $\begin{array}{c}\text { Temp } \\
\text { ( } \mathrm{C})\end{array}$ & $\begin{array}{c}\mathrm{C} / \mathrm{B} / \mathrm{S}^{b} \\
\text { ratio }\end{array}$ & \multicolumn{2}{|c|}{ Conversion $(\% / \mathrm{h})^{c}$} & $\begin{array}{l}\text { TOF } \\
\left(\mathrm{h}^{-1}\right)^{d}\end{array}$ \\
\hline 1 & $3 \cdot P_{6}$ & $\mathbf{a}$ & 25 & $\mathrm{THF}$ & 50 & $1 / 8 / 200$ & $99 / 0.17$ & & $-e$ \\
\hline 2 & $3 \cdot P_{6}$ & $\mathbf{a}$ & 8 & $\mathrm{THF}$ & 25 & $1 / 8 / 200$ & $27 / 0.5$ & $97 / 1$ & 543 \\
\hline 3 & $3 \cdot P_{6}$ & $\mathbf{a}$ & 25 & $\mathrm{THF}$ & 25 & $1 / 8 / 1500$ & $45 / 1$ & $58 / 2$ & 1560 \\
\hline 4 & $3 \cdot P_{6}$ & $\mathbf{a}$ & 25 & $\mathrm{THF}$ & 50 & $1 / 8 / 1500$ & $33 / 1$ & $49 / 2$ & 797 \\
\hline 5 & 4 & $\mathbf{a}$ & 25 & $\mathrm{THF}$ & 50 & $1 / 8 / 204$ & $61 / 1$ & $98 / 3$ & 144 \\
\hline 6 & 5 & $\mathbf{a}$ & 25 & $\mathrm{THF}$ & 25 & $1 / 0 / 200$ & $0 / 1$ & $0 / 3$ & $-e$ \\
\hline 7 & 5 & $\mathbf{a}$ & 25 & THF & 50 & $1 / 8 / 200$ & $15 / 0.17$ & $99 / 0.5$ & $-e$ \\
\hline 8 & 5 & $\mathbf{a}$ & 8 & $\mathrm{THF}$ & 25 & $1 / 8 / 200$ & $10 / 0.5$ & $99 / 1$ & 825 \\
\hline $9^{f}$ & $3 \cdot \mathbf{P F}_{6}$ & b & 25 & $\mathrm{CH}_{2} \mathrm{Cl}_{2}$ & 25 & $1 / 0 / 200$ & $0 / 2$ & $0 / 23$ & $-e$ \\
\hline $10^{f}$ & $\mathbf{3} \cdot \mathbf{B A} \mathbf{r}^{\mathrm{F}}$ & b & 25 & $\mathrm{CH}_{2} \mathrm{Cl}_{2}$ & 25 & $1 / 0 / 200$ & $0 / 2$ & $0 / 23$ & $-e$ \\
\hline $11^{f}$ & $3 \cdot P_{6}$ & c & 25 & $\mathrm{CH}_{2} \mathrm{Cl}_{2}$ & 25 & $1 / 0 / 200$ & $2 / 2$ & $11 / 18.5$ & $-e$ \\
\hline $12^{f}$ & $3 \cdot \mathbf{P F}_{6}$ & c & 25 & THF & 25 & $1 / 8 / 200$ & $5 / 2$ & $9 / 7$ & $-e$ \\
\hline
\end{tabular}

${ }^{a}$ Reactions were carried out in a $50 \mathrm{~mL}$ Parr hydrogenation reactor at the desired $\mathrm{H}_{2}$ pressure and temperature using the solvent of choice $(6 \mathrm{~mL}), \mathbf{3} \cdot \mathbf{P F} \mathbf{6}(4.7 \mu \mathrm{mol}), \mathbf{3} \cdot \mathbf{B A r}^{\mathbf{F}}(3.7 \mu \mathrm{mol}), \mathbf{4}(4.1 \mu \mathrm{mol})$ or $\mathbf{5}$ $(4.5 \mu \mathrm{mol})$ as the catalyst, and $\mathrm{KO}^{t} \mathrm{Bu}(33-38 \mu \mathrm{mmol})$ as the base if required. ${ }^{b} \mathrm{C} / \mathrm{B} / \mathrm{S}=$ catalyst to base 
to substrate ratio. ${ }^{c}$ Conversions for the hydrogenation of acetophenone were determined by GC analysis and are reported as an average of at least two runs. ${ }^{d}$ TOF $=$ turnover frequency, measured as the slope of the linear portion of [alcohol] versus time plot. ${ }^{e}$ TOF not measured. ${ }^{f}$ Conversions were determined by ${ }^{1} \mathrm{H}$ NMR spectroscopy.

Hydrogenation of trans- $\alpha$-methylstilbene did not proceed at high $\mathrm{H}_{2}$ pressure ( 25 bar) when complexes 3. $\mathbf{P F}_{6}$ or $3 \cdot \mathbf{B A} \mathbf{r}^{\mathbf{F}}$ were used as the catalysts in a non-coordinating solvent, dichloromethane (entries 9 and 10). It is known that the steric bulk of the $N$-substituent at the imidazol-2-ylidene ring in a series of oxazoline functionalized NHC iridium(I) complexes is crucial in determining the catalytic activity in hindered alkene hydrogenation. ${ }^{2,13 \mathrm{c}}$ The less hindered $\mathrm{C}-\mathrm{NH}_{2}$ ligand that was used in complex 3 could be responsible for the inactivity that was observed. Of note, cyclooctane was observed in the reaction mixture by ${ }^{1} \mathrm{H}$ NMR after the reaction was quenched in air. This indicates that the 1,5-dicyclooctadiene ligand was indeed hydrogenated during the course of reaction.

Iridium(I) complexes containing a phosphine and nitrogen-based chelating ligand are efficient catalysts for the hydrogenation of imines, ${ }^{28}$ an important industrial process for the preparation of fine chemicals. ${ }^{29}$ Complex 3.PF $\mathbf{6}$ catalyzed the hydrogenation of $N$-(1-phenyl-ethylidene)aniline very slowly in the absence of an alkoxide base and in a non-coordinating solvent, reaching a conversion of $11 \%$ to the corresponding secondary amine in $18.5 \mathrm{~h}$ (entry 11 ). Upon activation of the complex by $\mathrm{KO}^{t} \mathrm{Bu}$ and when the reaction was conducted in THF, this catalyzed the hydrogenation of the ketimine in $9 \%$ conversion in $7 \mathrm{~h}$ (entry 12). We previously reported a related ruthenium(II) catalyst containing such a $\mathrm{C}-\mathrm{NH}_{2}$ ligand for the hydrogenation of the same ketimine under milder reaction conditions. ${ }^{6 a}$

\section{Conclusions}

We have reported the synthesis of a square-planar iridium(I) complex containing a $\mathrm{C}-\mathrm{NH}_{2}$ ligand $(\mathbf{3} \cdot \mathbf{P F} \mathbf{6})$ by a transmetalation reaction starting from nickel(II) complex $\mathbf{1},\left[\mathrm{Ni}\left(\mathrm{C}-\mathrm{NH}_{2}\right)_{2}\right]\left(\mathrm{PF}_{6}\right)_{2}$, and $[\operatorname{Ir}(\operatorname{cod}) \mathrm{Cl}]_{2}$. An addition reaction of $\mathrm{HCl}$ with $\mathbf{3} \cdot \mathbf{P F}_{\mathbf{6}}$ afforded a mixture of two isomers of iridium(III) hydridochloride complex 5. One of the isomers, 5-cis-HCl, was structurally characterized, and it was found to have a rare geometry containing trans-H-Ir- $\mathrm{NH}_{2}$ and cis-H- $\mathrm{Ir}-\mathrm{Cl}$ groupings. The identity of the isomers of complex $\mathbf{5}$ was supported by computational studies, but the spectroscopic data is insufficient to definitively assign the structure of each of the isomers.

Iridium complexes $\mathbf{3}$ and $\mathbf{5}$ were tested in the hydrogenation of unsaturated bonds. They are catalysts in the $\mathrm{H}_{2}$-hydrogenation of acetophenone, with superior activity in comparison to their phosphine-amine analogue, complex 4, and to the half sandwich complexes $\mathbf{2 a}$ and $\mathbf{2 b}$ containing such a $\mathbf{C}-\mathrm{NH}_{2}$ ligand. However, complex $\mathbf{3}$ was ineffective as a catalyst for the hydrogenation of a hindered alkene. We attribute this to the presence of a less-hindered $\mathrm{C}-\mathrm{NH}_{2}$ ligand in comparison to the more active iridium $\mathrm{NHC}$ complexes with larger substituents on the nitrogen. 
Table 3. Selected Crystal Data, Data Collection and Refinement Parameters for Complexes 3·PF6, 4 and 5 -cis- $-\mathrm{HCl}^{a}$

\begin{tabular}{|c|c|c|c|}
\hline compound & $3 \cdot \mathbf{P F}_{6}$ & 4 & 5-cis-HCl \\
\hline empirical formula & $\mathrm{C}_{19} \mathrm{H}_{25} \mathrm{~F}_{6} \mathrm{IrN}_{3} \mathrm{P} \cdot 0.5 \mathrm{CH}_{2} \mathrm{Cl}_{2}$ & $\mathrm{C}_{27} \mathrm{H}_{30} \mathrm{~F}_{6} \mathrm{IrNP}_{2}$ & $\mathrm{C}_{19} \mathrm{H}_{26} \mathrm{ClF}_{6} \mathrm{IrN}_{3} \mathrm{P}$ \\
\hline FW & 675.05 & 736.66 & 669.05 \\
\hline lattice type & triclinic & triclinic & triclinic \\
\hline Space group & $P_{-1}$ & $P_{-1}$ & $P_{-1}$ \\
\hline$T, \mathrm{~K}$ & 150 & 150 & 150 \\
\hline$a, \AA$ & $10.4979(5)$ & $10.0278(6)$ & $9.2564(3)$ \\
\hline$b, \AA$ & $11.4423(5)$ & $11.2097(8)$ & $9.5870(3)$ \\
\hline$c, \AA$ & $21.5427(8)$ & $13.6893(10)$ & $13.6385(6)$ \\
\hline$\alpha, \operatorname{deg}$ & $74.930(3)$ & $105.988(3)$ & $107.410(2)$ \\
\hline$\beta, \operatorname{deg}$ & $88.535(3)$ & $104.585(3)$ & $91.275(2)$ \\
\hline$\gamma, \operatorname{deg}$ & $67.908(2)$ & $108.488(4)$ & $111.138(2)$ \\
\hline$V, \AA^{3}$ & $2307.71(17)$ & $1302.24(15)$ & $1065.56(7)$ \\
\hline$Z$ & 4 & 2 & 2 \\
\hline$\rho_{\text {calc }} / \mathrm{Mg} \mathrm{m}^{-3}$ & 1.943 & 1.879 & 2.085 \\
\hline$\mu(\mathrm{Mo}, \mathrm{K} \alpha), \mathrm{mm}^{-1}$ & 6.031 & 5.311 & 6.530 \\
\hline$F(000)$ & 1308 & 720 & 648 \\
\hline cryst. size, $\mathrm{mm}^{3}$ & $0.15 \times 0.08 \times 0.06$ & $0.08 \times 0.05 \times 0.04$ & $0.40 \times 0.20 \times 0.14$ \\
\hline range $\theta$ collected, deg & 2.62 to 27.47 & 2.87 to 27.46 & 2.66 to 27.54 \\
\hline reflns collected/unique & $25641 / 10365$ & $13000 / 5629$ & $11450 / 4782$ \\
\hline abs cor & \multicolumn{3}{|c|}{ semiempirical from equivalents } \\
\hline max and min transmission coeff & 0.727 and 0.453 & 0.810 and 0.632 & 0.432 and 0.223 \\
\hline parameters refined & 607 & 334 & 284 \\
\hline goodness of fit & 1.024 & 1.040 & 1.079 \\
\hline$R_{1}(I>2 \sigma(I))$ & 0.0577 & 0.0561 & 0.0377 \\
\hline$w R_{2}$ (all data) & 0.1512 & 0.1267 & 0.0912 \\
\hline peak and hole, e $\AA^{-3}$ & 5.449 and -2.322 & 2.581 and -2.161 & 3.659 and -2.145 \\
\hline
\end{tabular}

${ }^{a}$ Definition of R indices: $R_{1}=\sum\left(F_{o}-F_{c}\right) / \sum\left(F_{o}\right) ; w R_{2}=\left[\sum\left[w\left(F_{o}{ }^{2}-F_{c}^{2}\right)^{2}\right] / \sum\left[w\left(F_{o}^{2}\right)^{2}\right]\right]^{1 / 2}$

\section{Experimental Section}

Synthesis. All of the preparations and manipulations, except where otherwise stated, were carried out under a nitrogen or argon atmosphere using standard Schlenk-line and glovebox techniques. Dry and oxygen-free solvents were always used. The synthesis of bis[1-(2-aminomethylphenyl)-3methylimidazol-2-ylidene]nickel(II) hexafluorophosphate $\left(\left[\mathrm{Ni}\left(\mathrm{C}-\mathrm{NH}_{2}\right)_{2}\right]\left(\mathrm{PF}_{6}\right)_{2}, \mathbf{1}\right)$ has been reported previously. ${ }^{5}$ The syntheses of $\left[\mathrm{IrHCl}_{2}(\mathrm{cod})\right]_{2}{ }^{16}$ and 2-(diphenylphosphino)benzylamine $\left(\mathrm{P}-\mathrm{NH}_{2}\right)^{14}$ were reported in the literature. The iridium(I) dimer, $[\operatorname{Ir}(\operatorname{cod}) \mathrm{Cl}]_{2}$, was purchased from Strem Chemicals. All other reagents and solvents were purchased from commercial sources and were used as received. Deuterated solvents were purchased from Cambridge Isotope Laboratories and Sigma Aldrich and degassed and dried over activated molecular sieves prior to use. NMR spectra were recorded on a Varian 400 spectrometer operating at $400 \mathrm{MHz}$ for ${ }^{1} \mathrm{H}, 100 \mathrm{MHz}$ for ${ }^{13} \mathrm{C}, 161 \mathrm{MHz}$ for ${ }^{31} \mathrm{P}$ and $376 \mathrm{MHz}$ for ${ }^{19} \mathrm{~F}$. The ${ }^{1} \mathrm{H}$ and ${ }^{13} \mathrm{C}\left\{{ }^{1} \mathrm{H}\right\}$ NMR were measured relative to partially deuterated solvent peaks but are reported relative to tetramethylsilane (TMS). All ${ }^{19} \mathrm{~F}$ chemical shifts were measured relative to trichlorofluoromethane as an external reference. All ${ }^{31} \mathrm{P}$ chemical shifts were measured relative to $85 \%$ 
phosphoric acid as an external reference. All infrared spectra were recorded on a Nicolet 550 Magna-IR spectrometer. The elemental analysis was performed at the Department of Chemistry, University of Toronto, on a Perkin-Elmer $2400 \mathrm{CHN}$ elemental analyzer. Samples were handled under argon where it was appropriate.

Synthesis of [1-(2-Aminomethylphenyl)-3-methylimidazol-2-ylidene $]\left(\eta^{4}\right.$-1,5-cyclooctadiene)iridium(I) Hexafluorophosphate $\left(\left[\operatorname{Ir}\left(\mathbf{C}-\mathbf{N H}_{2}\right)(\mathbf{c o d})\right] \mathbf{P F}_{6}, 3 \cdot \mathbf{P F}_{6}\right)$. A Schlenk flask was charged with 1 $(67 \mathrm{mg}, 0.093 \mathrm{mmol})$ and $[\operatorname{Ir}(\mathrm{cod}) \mathrm{Cl}]_{2}(62 \mathrm{mg}, 0.092 \mathrm{mmol})$. Dry acetonitrile $(12 \mathrm{~mL})$ was added to the reaction mixture, and it was refluxed under an argon atmosphere for $2.5 \mathrm{~h}$ until a deep brown solution was obtained. The solvent was evaporated under reduced pressure, and the residue was extracted with dichloromethane $(4 \mathrm{~mL})$ and filtered through a pad of Celite under a nitrogen atmosphere. Addition of pentane $(12 \mathrm{~mL})$ to this solution afforded a yellow precipitate. This was collected on a glass frit, washed with pentane $(1 \mathrm{~mL})$ and dried in vacuo. Yield: $82 \mathrm{mg}, 70 \%$. Suitable crystals for an X-ray diffraction study were obtained by slow diffusion of diethyl ether into a saturated solution of $\mathbf{3} \cdot \mathbf{P F}_{6}$ in dichloromethane under a nitrogen atmosphere. ${ }^{1} \mathrm{H}$ NMR $\left(\mathrm{CD}_{2} \mathrm{Cl}_{2}, \delta\right): 7.56(\mathrm{~m}, 3-\mathrm{CH}$ of $\mathrm{Ph}, 1 \mathrm{H}), 7.53(\mathrm{~m}$, 4-CH and 5-CH of $\mathrm{Ph}, 2 \mathrm{H}), 7.47\left(\mathrm{dd}, J_{\mathrm{HH}}=1.34,6.92 \mathrm{~Hz}, 6-\mathrm{CH}\right.$ of $\left.\mathrm{Ph}, 1 \mathrm{H}\right), 7.21\left(\mathrm{~d}, J_{\mathrm{HH}}=1.96 \mathrm{~Hz}, 5-\right.$ $\mathrm{CH}$ of imid., $1 \mathrm{H}), 7.16\left(\mathrm{~d}, J_{\mathrm{HH}}=1.96 \mathrm{~Hz}, 4-\mathrm{CH}\right.$ of imid., $\left.1 \mathrm{H}\right), 4.50\left(\mathrm{~m}, \mathrm{CH}_{2}, 1 \mathrm{H}\right), 4.43\left(\mathrm{t}, J_{\mathrm{HH}}=6.98 \mathrm{~Hz}\right.$, olefinic C-H of $\left.\operatorname{cod}_{\text {trans to }} \mathrm{C}, 1 \mathrm{H}\right), 4.03\left(\mathrm{~s}, \mathrm{CH}_{3}, 3 \mathrm{H}\right), 3.95\left(\mathrm{br}, \mathrm{NH}_{2}, 2 \mathrm{H}\right), 3.52$ (m, olefinic $\mathrm{C}-\mathrm{H}$ of cod trans to c, $1 \mathrm{H}), 3.35\left(\mathrm{~m}, \mathrm{CH}_{2}, 1 \mathrm{H}\right), 3.27\left(\mathrm{~m}\right.$, olefinic $\mathrm{C}-\mathrm{H}$ of $\left.\operatorname{cod}_{\text {trans to } \mathrm{Cl}}, 2 \mathrm{H}\right), 2.35\left(\mathrm{~m}, \mathrm{CH}_{2}\right.$ of cod, $\left.1 \mathrm{H}\right), 2.14(\mathrm{~m}$, $\mathrm{CH}_{2}$ of cod, $\left.1 \mathrm{H}\right), 1.97\left(\mathrm{~m}, \mathrm{CH}_{2}\right.$ of cod, $\left.1 \mathrm{H}\right), 1.70\left(\mathrm{~m}, \mathrm{CH}_{2}\right.$ of cod, $\left.1 \mathrm{H}\right), 1.51\left(\mathrm{~m}, \mathrm{CH}_{2}\right.$ of cod, $\left.3 \mathrm{H}\right), 1.35(\mathrm{~m}$, $\mathrm{CH}_{2}$ of cod, $\left.1 \mathrm{H}\right) .{ }^{19} \mathrm{~F} \mathrm{NMR}\left(\mathrm{CD}_{2} \mathrm{Cl}_{2}, \delta\right):-72.6\left(\mathrm{~d}, J_{\mathrm{PF}}=712 \mathrm{~Hz}\right) .{ }^{13} \mathrm{C}\left\{{ }^{1} \mathrm{H}\right\} \mathrm{NMR}\left(\mathrm{CD}_{2} \mathrm{Cl}_{2}, \delta\right): 177.6(\mathrm{Ir}-$ $\left.\mathrm{C}_{\text {carbene }}\right), 139.6\left(\mathrm{C}_{\mathrm{Ph}}\right), 133.6\left(\mathrm{C}_{\mathrm{Ph}}\right), 131.7\left(\mathrm{C}_{\mathrm{Ph}}\right), 130.6\left(\mathrm{C}_{\mathrm{Ph}}\right), 129.6\left(\mathrm{C}_{\mathrm{Ph}}\right), 124.9\left(\mathrm{C}_{\mathrm{Ph}}\right), 123.5\left(\mathrm{C}_{\text {imid. }}\right), 122.5$ ( $\mathrm{C}_{\text {imid. }}$ ), 82.5 (olefinic $\mathrm{C}$ of $\operatorname{cod}_{\text {trans to }} \mathrm{C}$ ), 81.1 (olefinic $\mathrm{C}$ of $\operatorname{cod}_{\text {trans to }} \mathrm{C}$ ), 63.7 (olefinic $\mathrm{C}$ of $\operatorname{cod}_{\text {trans }}$ to $\mathrm{Cl}$ ), 57.2 (olefinic $\mathrm{C}$ of $\left.\operatorname{cod}_{\text {trans to } \mathrm{Cl}}\right), 47.0\left(\mathrm{CH}_{2}\right), 37.9\left(\mathrm{CH}_{3}\right), 34.7\left(\mathrm{CH}_{2}\right.$ of $\left.\operatorname{cod}\right), 32.1\left(\mathrm{CH}_{2}\right.$ of $\left.\operatorname{cod}\right), 30.8\left(\mathrm{CH}_{2}\right.$ of $\operatorname{cod}), 27.6\left(\mathrm{CH}_{2}\right.$ of cod). MS (ESI, methanol/water; $\left.\mathrm{m} / \mathrm{z}\right)$ : $488.2[\mathrm{M}]^{+}$. HRMS (ESI, methanol/water; $\mathrm{m} / \mathrm{z}$ ): calcd for $\mathrm{C}_{19} \mathrm{H}_{25} \mathrm{~N}_{3} \mathrm{Ir}^{+}[\mathrm{M}]^{+}$: 488.1672, found: 488.1627. Anal. Calcd for $\mathrm{C}_{19} \mathrm{H}_{25} \mathrm{~N}_{3} \mathrm{~F}_{6} \mathrm{PIr}$ : C, 36.07; H, 3.98; N, 6.64. Found: C, 36.24; H, 3.86; N, 6.57.

Synthesis of [1-(2-Aminomethylphenyl)-3-methylimidazol-2-ylidene $]\left(\eta^{4}-1,5\right.$-cyclooctadiene)iridium(I) Tetrakis(3,5-bis(trifluoromethyl)phenyl)borate $\left(\left[\operatorname{Ir}\left(\mathrm{C}-\mathrm{NH}_{2}\right)(\operatorname{cod})\right] \mathrm{BAr} \mathbf{r}^{\mathrm{F}}, 3 \cdot \mathrm{BAr}^{\mathrm{F}}\right)$. A scintillation vial with a threaded screw cap was charged with $\mathbf{3} \cdot \mathbf{P F} \mathbf{6}(20 \mathrm{mg}, 0.032 \mathrm{mmol})$ and sodium tetrakis(3,5-bis(trifluoromethyl)phenyl)borate $\left(\mathrm{NaB}\left(\mathrm{Ar}^{\mathrm{F}}\right)_{4}, 28 \mathrm{mg}, 0.032 \mathrm{mmol}\right)$ in dry dichloromethane $(6 \mathrm{~mL})$ under a nitrogen atmosphere. The solution was stirred overnight at $25^{\circ} \mathrm{C}$. The reaction mixture was then filtered through a pad of Celite, and the solvent was evaporated under reduced pressure to afford a yellow solid upon isolation. Yield: $31 \mathrm{mg}, 72 \% .{ }^{1} \mathrm{H} \mathrm{NMR}\left(\mathrm{CD}_{2} \mathrm{Cl}_{2}, \delta\right): 7.72$ (m, Ar-CH of BAr $\left.{ }^{\mathrm{F}}, 8 \mathrm{H}\right)$, $7.63\left(\mathrm{dt}, J_{\mathrm{HH}}=1.38,7.63 \mathrm{~Hz}, 5-\mathrm{CH}\right.$ of $\left.\mathrm{Ph}, 1 \mathrm{H}\right), 7.56\left(\mathrm{~m}, \mathrm{Ar}-\mathrm{CH}\right.$ of BAr${ }^{\mathrm{F}}, 3-\mathrm{CH}$ of Ph, 5H), $7.51\left(\mathrm{t}, J_{\mathrm{HH}}=\right.$ $7.86 \mathrm{~Hz}, 4-\mathrm{CH}$ of $\mathrm{Ph}, 1 \mathrm{H}), 7.43\left(\mathrm{dd}, J_{\mathrm{HH}}=1.00,7.60 \mathrm{~Hz}, 6-\mathrm{CH}\right.$ of $\left.\mathrm{Ph}, 1 \mathrm{H}\right), 7.23\left(\mathrm{~d}, J_{\mathrm{HH}}=1.90 \mathrm{~Hz}, 5-\mathrm{CH}\right.$ of imid., $1 \mathrm{H}), 7.13\left(\mathrm{~d}, J_{\mathrm{HH}}=1.90 \mathrm{~Hz}, 4-\mathrm{CH}\right.$ of imid., $\left.1 \mathrm{H}\right), 4.46\left(\mathrm{dd}, J_{\mathrm{HH}}=4.47,12.86 \mathrm{~Hz}, \mathrm{CH}_{2}, 1 \mathrm{H}\right), 4.29$ $\left(\mathrm{dt}, J_{\mathrm{HH}}=1.93,7.75 \mathrm{~Hz}\right.$, olefinic $\mathrm{C}-\mathrm{H}$ of $\left.\operatorname{cod}_{\text {trans to } \mathrm{C}}, 1 \mathrm{H}\right), 3.99\left(\mathrm{~s}, \mathrm{CH}_{3}, 3 \mathrm{H}\right), 3.68-3.60\left(\mathrm{br}, \mathrm{NH}_{2}\right.$, olefinic $\mathrm{C}-\mathrm{H}$ of $\left.\operatorname{cod}_{\text {trans to }}, 3 \mathrm{H}\right), 3.37$ (m, olefinic $\mathrm{C}-\mathrm{H}$ of $\left.\operatorname{cod}_{\text {trans to } \mathrm{Cl}}, \mathrm{CH}_{2}, 3 \mathrm{H}\right), 2.31$ (m, $\mathrm{CH}_{2}$ of cod, $\left.1 \mathrm{H}\right), 2.15$ (m, $\mathrm{CH}_{2}$ of cod, $\left.1 \mathrm{H}\right), 2.00\left(\mathrm{~m}, \mathrm{CH}_{2}\right.$ of cod, $\left.1 \mathrm{H}\right), 1.73\left(\mathrm{~m}, \mathrm{CH}_{2}\right.$ of cod, $\left.1 \mathrm{H}\right), 1.54\left(\mathrm{~m}, \mathrm{CH}_{2}\right.$ of cod, $\left.3 \mathrm{H}\right), 1.38$ (m, $\mathrm{CH}_{2}$ of cod, $\left.1 \mathrm{H}\right) .{ }^{19} \mathrm{~F}$ NMR $\left(\mathrm{CD}_{2} \mathrm{Cl}_{2}, \delta\right)$ : $-62.9\left(\mathrm{~s}, \mathrm{CF}_{3}\right.$ of $\left.\mathrm{BAr}^{\mathrm{F}}\right)$. The ${ }^{1} \mathrm{H}$ and ${ }^{19} \mathrm{~F}$ NMR spectra of the complex that was used for catalysis are given in the Supporting Information.

Synthesis of $\left(\eta^{4}\right.$-1,5-Cyclooctadiene)[2-(diphenylphosphino)benzylamine]iridium(I) Hexafluorophosphate $\left(\left[\operatorname{Ir}\left(\mathbf{P}-\mathbf{N H}_{2}\right)(\mathbf{c o d})\right] \mathbf{P F}_{6}, 4\right)$. A scintillation vial with a threaded screw cap was charged with $\left[\operatorname{Ir}(\operatorname{cod}) \mathrm{Cl}_{2}(45 \mathrm{mg}, 0.067 \mathrm{mmol}), 2\right.$-(diphenylphosphino)benzylamine (41 $\left.\mathrm{mg}, 0.13 \mathrm{mmol}\right)$ and silver hexafluorophosphate $(34 \mathrm{mg}, 0.13 \mathrm{mmol}$ ). Upon dissolution of the solids in a mixture of dichloromethane $(12 \mathrm{~mL})$ and acetonitrile $(2 \mathrm{~mL})$, the colour of the solution turned from orange to red along with the formation of a white precipitate. The reaction mixture was stirred for $2 \mathrm{~h}$ at $25^{\circ} \mathrm{C}$. After the reaction has 
gone to completion, the reaction mixture was filtered through a pad of Celite, and the volume of solvent was reduced $(1 \mathrm{~mL})$. Addition of diethyl ether $(12 \mathrm{~mL})$ to this solution afforded an orange-red precipitate, which was filtered and dried in vacuo. Yield: $56 \mathrm{mg}$, 57\%. Suitable crystals for an X-ray diffraction study were obtained by slow diffusion of diethyl ether into a saturated solution of $\mathbf{4}$ in dichloromethane under a nitrogen atmosphere. ${ }^{1} \mathrm{H}$ NMR $\left(\mathrm{CD}_{2} \mathrm{Cl}_{2}, \delta\right)$ : 7.58 - 7.51 (m, $\mathrm{Ar}-\mathrm{CH}$ of $\mathrm{PPh}_{2}, 4-\mathrm{CH}$ and 5-CH of $\left.\mathrm{Ph}, 12 \mathrm{H}\right)$, $7.41(\mathrm{~m}, 3-\mathrm{CH}$ of $\mathrm{Ph}, 1 \mathrm{H}), 7.36(\mathrm{~m}, 6-\mathrm{CH}$ of $\mathrm{Ph}, 1 \mathrm{H}), 4.90(\mathrm{~m}$, olefinic $\mathrm{C}-\mathrm{H}$ of cod trans to $\mathrm{P}, 2 \mathrm{H}), 4.21$ (br, $\left.\mathrm{NH}_{2}, 2 \mathrm{H}\right), 4.14\left(\mathrm{~m}, \mathrm{CH}_{2}, 2 \mathrm{H}\right), 3.13\left(\mathrm{~m}\right.$, olefinic $\mathrm{C}-\mathrm{H}$ of $\left.\operatorname{cod}_{\text {trans to } \mathrm{Cl}}, 2 \mathrm{H}\right), 2.28\left(\mathrm{~m}, \mathrm{CH}_{2}\right.$ of cod, $\left.4 \mathrm{H}\right), 2.02$ (m, $\mathrm{CH}_{2}$ of cod, $\left.2 \mathrm{H}\right), 1.90\left(\mathrm{~m}, \mathrm{CH}_{2}\right.$ of $\left.\operatorname{cod}, 2 \mathrm{H}\right) .{ }^{19} \mathrm{~F} \mathrm{NMR}\left(\mathrm{CD}_{2} \mathrm{Cl}_{2}, \delta\right):-72.6\left(\mathrm{~d}, J_{\mathrm{PF}}=712 \mathrm{~Hz}\right) .{ }^{31} \mathrm{P}\left\{{ }^{1} \mathrm{H}\right\}$ $\mathrm{NMR}\left(\mathrm{CD}_{2} \mathrm{Cl}_{2}, \delta\right): 12.6(\mathrm{~s}),-144.4\left(\mathrm{sept}, J_{\mathrm{PF}}=712 \mathrm{~Hz}\right) .{ }^{13} \mathrm{C}\left\{{ }^{1} \mathrm{H}\right\} \mathrm{NMR}\left(\mathrm{CD}_{2} \mathrm{Cl}_{2}, \delta\right): 140.6\left(\mathrm{~d}, J_{\mathrm{CP}}=14.42\right.$ $\left.\mathrm{Hz}, \mathrm{C}_{\mathrm{Ph}}\right), 135.0\left(\mathrm{~d}, J_{\mathrm{CP}}=11.50 \mathrm{~Hz}, \mathrm{C}_{\mathrm{PPh}}\right), 132.7\left(\mathrm{~d}, J_{\mathrm{CP}}=8.65 \mathrm{~Hz}, \mathrm{C}_{\mathrm{Ph}}\right), 132.3\left(\mathrm{~d}, J_{\mathrm{CP}}=3.21 \mathrm{~Hz}, \mathrm{C}_{\mathrm{Ph}}\right)$, $132.2\left(\mathrm{~d}, J_{\mathrm{CP}}=2.46 \mathrm{~Hz}, \mathrm{C}_{\mathrm{Ph}}\right), 132.0\left(\mathrm{~d}, J_{\mathrm{CP}}=2.17 \mathrm{~Hz}, \mathrm{C}_{\mathrm{Ph}}\right), 130.4\left(\mathrm{~d}, J_{\mathrm{CP}}=7.51 \mathrm{~Hz}, \mathrm{C}_{\mathrm{Ph}}\right), 129.6\left(\mathrm{~d}, J_{\mathrm{CP}}=\right.$ $\left.10.65 \mathrm{~Hz}, \mathrm{C}_{\mathrm{PPh}}\right), 126.8\left(\mathrm{~d}, J_{\mathrm{CP}}=48.26 \mathrm{~Hz}, \mathrm{C}_{\mathrm{PPh}}\right), 126.6\left(\mathrm{~d}, J_{\mathrm{CP}}=54.11 \mathrm{~Hz}, \mathrm{C}_{\mathrm{PPh}}\right), 93.2\left(\mathrm{~d}, J_{\mathrm{CP}}=12.00 \mathrm{~Hz}\right.$, olefinic $\mathrm{C}$ of $\operatorname{cod}_{\text {trans to P) }}, 63.9$ (olefinic $\mathrm{C}$ of $\left.\operatorname{cod}_{\text {trans to } \mathrm{Cl}}\right), 47.7\left(\mathrm{~d}, J_{\mathrm{CP}}=10.48 \mathrm{~Hz}, \mathrm{CH}_{2}\right), 32.6\left(\mathrm{~d}, J_{\mathrm{CP}}=\right.$ $3.21 \mathrm{~Hz}, \mathrm{CH}_{2}$ of cod), $29.8\left(\mathrm{CH}_{2}\right.$ of cod). MS (ESI, methanol/water; $\left.m / z\right): 592.2[\mathrm{M}]^{+}$. HRMS (ESI, methanol/water; $\mathrm{m} / \mathrm{z}$ ): calcd for $\mathrm{C}_{27} \mathrm{H}_{30} \mathrm{NPIr}^{+}[\mathrm{M}]^{+}$: 592.1739, found: 592.1711. Anal. Calcd for $\mathrm{C}_{27} \mathrm{H}_{30} \mathrm{NF}_{6} \mathrm{P}_{2} \mathrm{Ir}: \mathrm{C}, 44.02 ; \mathrm{H}, 4.10 ; \mathrm{N}, 1.90$. Found: $\mathrm{C}, 43.94 ; \mathrm{H}, 3.92 ; \mathrm{N}, 2.05$.

Synthesis of [1-(2-Aminomethylphenyl)-3-methylimidazol-2-ylidene $] \operatorname{chloro}\left(\eta^{4}-1,5-\right.$ cyclooctadiene)hydridoiridium(III) Hexafluorophosphate $\left(\left[\mathrm{IrHCl}\left(\mathrm{C}-\mathrm{NH}_{2}\right)(\mathbf{c o d})\right] \mathbf{P F} 6,5\right)$. A Schlenk flask was charged with $\mathbf{3} \cdot \mathbf{P F}_{6}(50 \mathrm{mg}, 0.079 \mathrm{mmol})$ in $\mathrm{THF}(25 \mathrm{~mL})$. The solution was cooled to $-78^{\circ} \mathrm{C}$. To this was added dropwise $1.0 \mathrm{M}$ hydrochloric acid in ethereal solution $(0.08 \mathrm{~mL}$, diluted with THF, ca. $8 \mathrm{~mL}$ in total volume), and the resultant solution was stirred further for $3 \mathrm{~h}$ at $-78^{\circ} \mathrm{C}$. The solvent was then evaporated under reduced pressure, and the residue was redissolved in THF ( $2 \mathrm{~mL})$. Addition of pentane $(15 \mathrm{~mL})$ afforded a pale yellow precipitate. This was collected on a glass frit and dried in vacuo. Yield: $39 \mathrm{mg}, 74 \%$. The major isomer (over $90 \%$ of the product) slowly isomerize in solution to give approximately 1 to 1 ratio of the 5-cis-HCl and 5-trans-HCl isomers, as identified by ${ }^{1} \mathrm{H}$ NMR. Alternatively, the title compound can be prepared by the reaction of $\left[\mathrm{IrHCl}_{2}(\mathrm{cod})\right]_{2}(62 \mathrm{mg}, 0.083 \mathrm{mmol})$ and $1(60 \mathrm{mg}, 0.083 \mathrm{mmol})$ in refluxing acetonitrile $(15 \mathrm{~mL})$ for $2.5 \mathrm{~h}$. The solvent was then evaporated under reduced pressure, and the residue was extracted with THF $(5 \mathrm{~mL})$ and filtered through a pad of Celite. Addition of diethyl ether $(15 \mathrm{~mL})$ afforded a pale yellow precipitate, which was filtered and dried in vacuo. Yield: $70 \mathrm{mg}, 63 \%$. This gave approximately 1 to 1 ratio of the two isomers as identified by ${ }^{1} \mathrm{H}$ NMR. Suitable crystals of the 5-cis-HCl isomer for an X-ray diffraction study were obtained by slow diffusion of diethyl ether into a saturated solution of $\mathbf{5}$ in THF under a nitrogen atmosphere. The spectral data pertaining to the major and minor isomers are provided below, but these are given without assigning to the isomers 5-cis-HCl and 5-trans-HCl. Major isomer: ${ }^{1} \mathrm{H}$ NMR (THF- $\left.d_{8}, \delta\right)$ : 7.69 (m, 3-CH and 5$\mathrm{CH}$ of $\mathrm{Ph}, 2 \mathrm{H}), 7.62(\mathrm{~m}, 4-\mathrm{CH}$ and 6-CH of $\mathrm{Ph}, 2 \mathrm{H}), 7.54\left(\mathrm{~d}, J_{\mathrm{HH}}=2.05 \mathrm{~Hz}, 5-\mathrm{CH}\right.$ of imid., $\left.1 \mathrm{H}\right), 7.37$ (d, $J_{\mathrm{HH}}=2.05 \mathrm{~Hz}, 4-\mathrm{CH}$ of imid., $\left.1 \mathrm{H}\right), 4.99\left(\mathrm{br}, \mathrm{NH}_{2}, 1 \mathrm{H}\right), 4.83\left(\mathrm{~m}\right.$, olefinic C-H of cod, 2H), $4.72\left(\mathrm{br}, \mathrm{NH}_{2}\right.$, $1 \mathrm{H}), 4.40\left(\mathrm{t}, J_{\mathrm{HH}}=7.61 \mathrm{~Hz}\right.$, olefinic $\mathrm{C}-\mathrm{H}$ of cod, $\left.1 \mathrm{H}\right), 4.29\left(\mathrm{~s}, \mathrm{CH}_{3}, 3 \mathrm{H}\right), 4.18\left(\mathrm{~m}, \mathrm{CH}_{2}, 1 \mathrm{H}\right), 4.03\left(\mathrm{t}, J_{\mathrm{HH}}\right.$ $=7.44 \mathrm{~Hz}$, olefinic C-H of cod, $1 \mathrm{H}), 3.16\left(\mathrm{dt}, J_{\mathrm{HH}}=3.91,12.30 \mathrm{~Hz}, \mathrm{CH}_{2}, 1 \mathrm{H}\right), 3.06\left(\mathrm{~m}, \mathrm{CH}_{2}\right.$ of cod, $\left.1 \mathrm{H}\right)$, $2.85\left(\mathrm{~m}, \mathrm{CH}_{2}\right.$ of cod, 1H), $2.57\left(\mathrm{~m}, \mathrm{CH}_{2}\right.$ of cod, $\left.1 \mathrm{H}\right), 2.32\left(\mathrm{~m}, \mathrm{CH}_{2}\right.$ of cod, 1H), $2.15\left(\mathrm{~m}, \mathrm{CH}_{2}\right.$ of cod, 1H), $2.10\left(\mathrm{~m}, \mathrm{CH}_{2}\right.$ of cod, $\left.1 \mathrm{H}\right), 1.78\left(\mathrm{~m}, \mathrm{CH}_{2}\right.$ of cod, $\left.1 \mathrm{H}\right), 1.68\left(\mathrm{~m}, \mathrm{CH}_{2}\right.$ of cod, $\left.1 \mathrm{H}\right),-14.61(\mathrm{~s}, \mathrm{Ir}-\mathrm{H}) .{ }^{19} \mathrm{~F}$ NMR $\left(\mathrm{THF}-d_{8}, \delta\right):-71.1\left(\mathrm{~d}, J_{\mathrm{PF}}=711 \mathrm{~Hz}\right) .{ }^{13} \mathrm{C}\left\{{ }^{1} \mathrm{H}\right\}$ NMR $\left(\mathrm{THF}-d_{8}, \delta\right): 147.0\left(\mathrm{Ir}-\mathrm{C}_{\text {carbene }}\right), 141.4\left(\mathrm{C}_{\mathrm{Ph}}\right), 133.7$ $\left(\mathrm{C}_{\mathrm{Ph}}\right), 132.8\left(\mathrm{C}_{\mathrm{Ph}}\right), 131.5\left(\mathrm{C}_{\mathrm{Ph}}\right), 130.5\left(\mathrm{C}_{\mathrm{Ph}}\right), 126.7\left(\mathrm{C}_{\mathrm{Ph}}\right), 126.1\left(\mathrm{C}_{\text {imid. }}\right), 124.3\left(\mathrm{C}_{\mathrm{imid}}\right), 96.8$ (olefinic $\mathrm{C}$ of cod), 94.7 (olefinic $\mathrm{C}$ of cod), 75.6 (olefinic $\mathrm{C}$ of cod), 75.0 (olefinic $\mathrm{C}$ of cod), $47.5\left(\mathrm{CH}_{2}\right), 38.7\left(\mathrm{CH}_{3}\right)$, $38.5\left(\mathrm{CH}_{2}\right.$ of cod), $29.8\left(\mathrm{CH}_{2}\right.$ of cod), $29.1\left(\mathrm{CH}_{2}\right.$ of cod), $28.7\left(\mathrm{CH}_{2}\right.$ of cod). Minor isomer: ${ }^{1} \mathrm{H}$ NMR (THF$\left.d_{8}, \delta\right): 7.99\left(\mathrm{~d}, J_{\mathrm{HH}}=7.47 \mathrm{~Hz}, 3-\mathrm{CH}\right.$ of $\left.\mathrm{Ph}, 1 \mathrm{H}\right), 7.64\left(\mathrm{t}, J_{\mathrm{HH}}=7.51 \mathrm{~Hz}, 4-\mathrm{CH}\right.$ of Ph, 1H), $7.57\left(\mathrm{dt}, J_{\mathrm{HH}}=\right.$ $1.04,7.64 \mathrm{~Hz}, 5-\mathrm{CH}$ of of $\mathrm{Ph}, 1 \mathrm{H}), 7.53\left(\mathrm{~d}, J_{\mathrm{HH}}=1.96 \mathrm{~Hz}, 5-\mathrm{CH}\right.$ of imid., $\left.1 \mathrm{H}\right), 7.42\left(\mathrm{~d}, J_{\mathrm{HH}}=1.96 \mathrm{~Hz}, 4-\right.$ $\mathrm{CH}$ of imid., $1 \mathrm{H}), 7.37\left(\mathrm{dd}, J_{\mathrm{HH}}=1.10,7.86 \mathrm{~Hz}, 6-\mathrm{CH}\right.$ of $\left.\mathrm{Ph}, 1 \mathrm{H}\right), 5.38\left(\mathrm{dt}, J_{\mathrm{HH}}=3.14,8.44 \mathrm{~Hz}\right.$, olefinic C-H of cod, 1H), 5.10 (br, $\left.\mathrm{NH}_{2}, 1 \mathrm{H}\right), 4.78$ (m, olefinic C-H of cod, 1H), 4.71 (br, $\left.\mathrm{NH}_{2}, 1 \mathrm{H}\right), 4.54\left(\mathrm{~m}, \mathrm{CH}_{2}\right.$, $1 \mathrm{H}), 4.34(\mathrm{~m}$, olefinic $\mathrm{C}-\mathrm{H}$ of cod, $1 \mathrm{H}), 4.27\left(\mathrm{~s}, \mathrm{CH}_{3}, 3 \mathrm{H}\right), 4.00(\mathrm{~m}$, olefinic $\mathrm{C}-\mathrm{H}$ of cod, $1 \mathrm{H}), 3.81(\mathrm{dt}$, 
$\left.J_{\mathrm{HH}}=3.28,7.94 \mathrm{~Hz}, \mathrm{CH}_{2}, 1 \mathrm{H}\right), 2.77\left(\mathrm{~m}, \mathrm{CH}_{2}\right.$ of cod, $\left.1 \mathrm{H}\right), 2.57\left(\mathrm{~m}, \mathrm{CH}_{2}\right.$ of cod, $\left.1 \mathrm{H}\right), 2.33-2.26\left(\mathrm{~m}, \mathrm{CH}_{2}\right.$ of cod, 2H), $2.14\left(\mathrm{~m}, \mathrm{CH}_{2}\right.$ of cod, $\left.1 \mathrm{H}\right), 2.04\left(\mathrm{~m}, \mathrm{CH}_{2}\right.$ of cod, $\left.1 \mathrm{H}\right), 1.89\left(\mathrm{~m}, \mathrm{CH}_{2}\right.$ of cod, $\left.1 \mathrm{H}\right), 1.56\left(\mathrm{~m}, \mathrm{CH}_{2}\right.$ of cod, $1 \mathrm{H}),-12.48(\mathrm{~s}, \mathrm{Ir}-\mathrm{H}) .{ }^{19} \mathrm{~F}$ NMR $\left(\mathrm{THF}-d_{8}, \delta\right):-71.1\left(\mathrm{~d}, J_{\mathrm{PF}}=711 \mathrm{~Hz}\right) .{ }^{13} \mathrm{C}\left\{{ }^{1} \mathrm{H}\right\} \mathrm{NMR}\left(\mathrm{THF}-d_{8}, \delta\right)$ : $147.8\left(\mathrm{Ir}-\mathrm{C}_{\text {carbene }}\right), 139.3\left(\mathrm{C}_{\mathrm{Ph}}\right), 133.4\left(\mathrm{C}_{\mathrm{Ph}}\right), 132.5\left(\mathrm{C}_{\mathrm{Ph}}\right), 131.8\left(\mathrm{C}_{\mathrm{Ph}}\right), 130.8\left(\mathrm{C}_{\mathrm{Ph}}\right), 126.6\left(\mathrm{C}_{\mathrm{Ph}}\right), 126.2$ ( $\left.\mathrm{C}_{\text {imid.) }}\right) 124.9$ ( $\left.\mathrm{C}_{\text {imid.) }}\right), 102.2$ (olefinic $\mathrm{C}$ of cod), 95.8 (olefinic $\mathrm{C}$ of cod), 70.4 (olefinic $\mathrm{C}$ of cod), 68.2 (olefinic $\mathrm{C}$ of cod), $46.8\left(\mathrm{CH}_{2}\right), 40.6\left(\mathrm{CH}_{3}\right), 35.1\left(\mathrm{CH}_{2}\right.$ of cod), $35.0\left(\mathrm{CH}_{2}\right.$ of cod), $32.6\left(\mathrm{CH}_{2}\right.$ of cod), 31.7 $\left(\mathrm{CH}_{2}\right.$ of cod). MS (ESI, methanol/water; m/z): $524.1[\mathrm{M}]^{+}, 488.2[\mathrm{M}-\mathrm{HCl}]^{+}$. HRMS (ESI, methanol/water; $\mathrm{m} / \mathrm{z}$ ): calcd for $\mathrm{C}_{19} \mathrm{H}_{26} \mathrm{~N}_{3} \mathrm{ClIr}^{+}[\mathrm{M}]^{+}:$524.1439, found: 524.1408. IR $\left(\mathrm{KBr} \mathrm{cm}^{-1}\right): 2238$, 2244 (br, $v(\mathrm{Ir}-\mathrm{H})$ ). Anal. Calcd for $\mathrm{C}_{19} \mathrm{H}_{26} \mathrm{~N}_{3} \mathrm{ClF}_{6} \mathrm{PIr}$ : C, 34.11; H, 3.92; N, 6.28. Found: C, 34.30; H, 3.98; N, 5.99 .

Synthesis of [1-(2-Aminomethylphenyl)-3-methylimidazol-2-ylidene]chloro $\left(\eta^{4}-1,5\right.$-cyclooctadiene $)$ deuteridoiridium(III) Hexafluorophosphate $\left(\left[\operatorname{IrDCl}\left(\mathbf{C}-\mathbf{N H}_{2}\right)(\operatorname{cod})\right] \mathbf{P F}_{6}, 5-d_{1}\right)$. The preparation of the title compound was similar to that of $\mathbf{4}$, starting with $\mathbf{3} \cdot \mathbf{P F} \mathbf{6}(47 \mathrm{mg}, 0.074 \mathrm{mmol}$ ) and $1.0 \mathrm{M}$ deuterium chloride in ethereal solution $(97.5 \%$ atom $\mathrm{D}, 0.08 \mathrm{~mL}$, diluted with THF, ca. $8 \mathrm{~mL}$ in total volume). A pale yellow solid was obtained by the precipitation of $\mathbf{5}-\boldsymbol{d}_{\mathbf{1}}$ in THF $(2 \mathrm{~mL})$ with pentane (15 mL). Yield: $43 \mathrm{mg}, 86 \%$. The major isomer slowly isomerizes in solution to give approximately 1 to 1 ratio of the two isomers, as identified by ${ }^{1} \mathrm{H}$ NMR. The ${ }^{1} \mathrm{H}$ NMR spectrum of the title complex (THF- $\left.d_{8}\right)$ was similar to that of 5, except for a reduce ${ }^{1} \mathrm{H}$ integration at the hydride resonance at $-14.61 \mathrm{ppm}$. IR $\left(\mathrm{KBr} \mathrm{cm}^{-1}\right): 2241$ (br, $v(\mathrm{Ir}-\mathrm{D})$ ). Several attempts at elemental analyses failed to give an acceptable nitrogen content. Typical results: Anal. Calcd for $\mathrm{C}_{19} \mathrm{H}_{25} \mathrm{DN}_{3} \mathrm{ClF}_{6} \mathrm{PIr}$ : C, 34.06; H, 4.06; N, 6.27. Found: C, 34.97; H, 3.50; N, 6.78.

X-ray Crystal Structure Determination. Single-crystal X-ray diffraction data were collected using a Nonius Kappa-CCD diffractometer with Mo Karadiation $(\lambda=0.71073 \AA)$ at $150 \mathrm{~K}$. The CCD data were integrated and scaled using the Denzo-SMN package. The structure was solved and refined using SHELXTL V6.1. Refinement was by full-matrix least-squares on $F^{2}$ using all data. Details are listed in Table 3.

Catalysis. Oxygen-free tetrahydrofuran (THF) used for all of the catalytic runs was stirred over sodium for 2-3 days under argon, and freshly distilled from sodium benzophenone ketyl prior to use. Acetophenone was vacuum distilled over phosphorus pentoxide $\left(\mathrm{P}_{2} \mathrm{O}_{5}\right)$ and stored under nitrogen prior to use. All of the hydrogenation reactions were performed at constant pressures using a stainless steel $50 \mathrm{~mL}$ Parr hydrogenation reactor. The temperature was maintained at 25 or $50^{\circ} \mathrm{C}$ using a constant temperature water bath. The reactor was flushed several times with hydrogen gas at 2-4 bar prior to the addition of catalyst and substrate, and base solutions.

In a typical run (entry 2 , Table 2$)$, catalyst $\mathbf{3} \cdot \mathbf{P F}_{6}(3 \mathrm{mg}, 4.7 \mu \mathrm{mol})$ and acetophenone (114 mg, $\left.0.95 \mathrm{mmol}\right)$, and potassium tert-butoxide ( $4 \mathrm{mg}, 0.036 \mathrm{mmol}$ ) were dissolved in THF (4 mL and $2 \mathrm{~mL}$, respectively) under a nitrogen atmosphere. The catalyst/substrate and base solutions were taken up by means of two separate syringes and needles in a glovebox. The needles were stoppered and the syringes were taken to the reactor. The solutions were then injected into the reactor against a flow of hydrogen gas. The hydrogen gas was adjusted to 8 bar. Small aliquots of the reaction mixture were quickly withdrawn with a syringe and a needle under a flow of hydrogen at timed intervals by venting the Parr reactor at reduced pressure. Alternatively, small aliquots of the reaction mixture were sampled from a stainless steel sampling dip tube attached to a modified Parr reactor. The dip tube was $30 \mathrm{~cm}$ in length with an inner diameter of 0.01 inches, and a swing valve was attached to the end of the sampling tube. Other technical details were previously reported. ${ }^{30}$ Two small aliquots of samples were thereby withdrawn quickly at timed intervals by opening the swing valve, and the first two aliquots were discarded. All samples for gas chromatography (GC) analyses were diluted to a total volume of approximately $2 \mathrm{~mL}$ using oxygenated THF. 
A Perkin-Elmer Clarus 400 chromatograph equipped with a chiral column (CP chirasil-Dex CB $25 \mathrm{~m} \mathrm{x}$ $2.5 \mathrm{~mm}$ ) with an auto-sampling capability was used for GC analyses. Hydrogen was used as the mobile phase at a column pressure of 5 psi with a split flow rate of $50 \mathrm{~mL} / \mathrm{min}$. The injector temperature was $250^{\circ} \mathrm{C}$, the FID temperature was $275^{\circ} \mathrm{C}$ and the oven temperature was $130^{\circ} \mathrm{C}$. Retention times $\left(\mathrm{t}_{\mathrm{R}} / \mathrm{min}\right)$ for acetophenone: 4.56; $(R)$-1-phenylethanol: 7.58; $(S)$-1-phenylethanol: 8.03. Conversions for the hydrogenation of trans- $\alpha$-methylstilbene and $N$-(1-phenyl-ethylidene)aniline were determined by ${ }^{1} \mathrm{H}$ NMR spectroscopy in $\mathrm{CDCl}_{3}$. All of the conversions were reported as an average of two GC runs. The reported conversions were reproducible.

Computational Details. All density functional theory (DFT) calculations were performed using the Gaussian $09^{31}$ package with the restricted hybrid mPW1PW91 ${ }^{21}$ or the $M 06^{23}$ functional along with the use of an ultrafine grid. The latter was shown to give better predictions of geometric parameters in organometallic compounds. ${ }^{23 \mathrm{~b},}{ }^{32}$ Iridium was treated with the $\mathrm{SDD}^{22}$ relativistic effective core potential and an associated basic set. All other atoms were treated with the double- $\zeta$ basis set $6-31++\mathrm{G}^{* *}$ which includes diffuse functionals ${ }^{33}$ and additional $p$-orbitals on hydrogen as well as additional $d$-orbitals on carbon, nitrogen and chlorine. ${ }^{34}$ All geometry optimization were conducted in the gas phase, and the stationary points were characterized by normal mode analysis. Reported free energies were obtained at 1 atm and $298 \mathrm{~K}$ using unscaled vibrational frequencies.

Acknowledgment. The NSERC Canada is thanked for a Discovery Grant to R.H.M and a graduate scholarship to W.W.N.O.

Supporting Information Available: X-ray structural data in crystallographic file (CIF) format for complexes 3·PF6, 4, and 5-cis-HCl; cartesian coordinates and energies for all of the computed structures, and the complete citation for reference 30 in PDF format.

\section{References}

1. (a) Hahn, F. E.; Jahnke, M. C., Angew. Chem.-Int. Edit. 2008, 47, 3122-3172; (b) Normand, A. T.; Cavell, K. J., Eur. J. Inorg. Chem. 2008, 2781-2800; (c) Diez-Gonzalez, S.; Marion, N.; Nolan, S. P., Chem. Rev. 2009, 109, 3612-3676.

2. Cui, X. H.; Burgess, K., Chem. Rev. 2005, 105, 3272-3296.

3. Hanasaka, F.; Fujita, K.-i.; Yamaguchi, R., Organometallics 2006, 25, 4643-4647.

4. (a) Clapham, S. E.; Hadzovic, A.; Morris, R. H., Coord. Chem. Rev. 2004, 248, 2201-2237; (b) Askevold, B.; Roesky, H. W.; Schneider, S., ChemCatChem 2012, 4, 307-320.

5. O, W. W. N.; Lough, A. J.; Morris, R. H., Organometallics 2009, 28, 6755-6761.

6. (a) O, W. W. N.; Lough, A. J.; Morris, R. H., Chem. Commun. 2010, 46, 8240 - 8242; (b) O, W. W. N.; Lough, A. J.; Morris, R. H., Organometallics 2011, 30, 1236-1252.

7. $\quad$ O, W. W. N.; Lough, A. J.; Morris, R. H., Organometallics 2012, 31, 2152-2165.

8. O, W. W. N.; Morris, R. H., ACS Catal. 2013, 3, 32-40.

9. (a) Cross, W. B.; Daly, C. G.; Boutadla, Y.; Singh, K., Dalton Trans. 2011, 40, 9722-9730. (b) Zinner, S. C.; Rentzsch, C. F.; Herdtweck, E.; Herrmann, W. A.; Kühn, F. E. Dalton Trans., 2009, 70557062. (c) Gülcemal, S.; Gokce, A. G.; Cetinkaya, B. Dalton Trans. 2013, 42, 7305-7311.

10. (a) Dahlenburg, L.; Gotz, R., Eur. J. Inorg. Chem. 2004, 888-905; (b) Dahlenburg, L.; Gotz, R., Inorg. Chim. Acta 2004, 357, 2875-2880; (c) Dong, Z.-R.; Li, Y.-Y.; Chen, J.-S.; Li, B.-Z.; Xing, Y.; Gao, J.-X., Org. Lett. 2005, 7, 1043-1045; (d) Clarke, Z. E.; Maragh, P. T.; Dasgupta, T. P.; Gusev, D. G.; Lough, A. J.; Abdur-Rashid, K., Organometallics 2006, 25, 4113-4117; (e) Choualeb, A.; Lough, A. J.; Gusev, D. G., Organometallics 2007, 26, 5224-5229; (f) Chen, X. H.; Jia, W. L.; Guo, R. W.; Graham, T. W.; Gullons, M. A.; Abdur-Rashid, K., Dalton Trans. 2009, 1407-1410.

11. (a) Field, L. D.; Messerle, B. A.; Vuong, K. Q.; Turner, P., Organometallics 2005, 24, 4241-4250; (b) Nanchen, S.; Pfaltz, A., Chem. Eur. J. 2006, 12, 4550-4558; (c) Jong, H.; Patrick, B. O.; Fryzuk, M. 
D., Can. J. Chem. 2008, 86, 803-810; (d) O, W. W. N.; Lough, A. J.; Morris, R. H., Organometallics 2009, 28, 853-862; (e) Jimenez, M. V.; Fernandez-Tornos, J.; Perez-Torrente, J. J.; Modrego, F. J.; Winterle, S.; Cunchillos, C.; Lahoz, F. J.; Oro, L. A., Organometallics 2011, 30, 5493-5508.

12. (a) Hillier, A. C.; Lee, H. M.; Stevens, E. D.; Nolan, S. P., Organometallics 2001, 20, 4246-4252; (b) Chianese, A. R.; Li, X.; Janzen, M. C.; Faller, J. W.; Crabtree, R. H., Organometallics 2003, 22, 16631667; (c) Kelly III, R. A.; Clavier, H.; Giudice, S.; Scott, N. M.; Stevens, E. D.; Bordner, J.; Samardjiev, I.; Hoff, C. D.; Cavallo, L.; Nolan, S. P., Organometallics 2007, 27, 202-210; (d) Zinner, S. C.; Rentzsch, C. F.; Herdtweck, E.; Herrmann, W. A.; Kuhn, F. E., Dalton Trans. 2009, 7055-7062.

13. (a) Lightfoot, A.; Schnider, P.; Pfaltz, A., Angew. Chem.-Int. Edit. 1998, 37, 2897-2899; (b) Hou, D. R.; Reibenspies, J.; Colacot, T. J.; Burgess, K., Chem. Eur. J. 2001, 7, 5391-5400; (c) Powell, M. T.; Hou, D.-R.; Perry, M. C.; Cui, X.; Burgess, K., J. Am. Chem. Soc. 2001, 123, 8878-8879.

14. Cahill, J. P.; Bohnen, F. M.; Goddard, R.; Kruger, C.; Guiry, P. J., Tetrahedron: Asymmetry 1998, 9, 3831-3839.

15. Attempts to control the stoichiometry of $\mathrm{HCl}$ (from 3 to 1.3 equiv) with respect to $\mathbf{3} \cdot \mathbf{P F 6}$, and the reaction temperature (from $25^{\circ} \mathrm{C}$ to $-78^{\circ} \mathrm{C}$ ) failed to give a single isomer upon isolation.

16. Robinson, S. D.; Shaw, B. L., J. Chem. Soc. 1965, 4997-5001.

17. (a) Viciano, M.; Mas-Marzá, E.; Poyatos, M.; Sanaú, M.; Crabtree, R. H.; Peris, E., Angew. Chem.Int. Edit. 2005, 44, 444; (b) Torres, O.; Martin, M.; Sola, E., Organometallics 2009, 28, 863-870.

18. (a) Danopoulos, A. A.; Winston, S.; Hursthouse, M. B., Dalton Trans. 2002, 3090-3091; (b) Tang, C. Y.; Smith, W.; Thompson, A. L.; Vidovic, D.; Aldridge, S., Angew. Chem.-Int. Edit. 2011, 50, 13591362.

19. Vicent, C.; Viciano, M.; Mas-Marza, E.; Sanau, M.; Peris, E., Organometallics 2006, 25, 3713 3720 .

20. (a) Abbel, R.; Abdur-Rashid, K.; Faatz, M.; Hadzovic, A.; Lough, A. J.; Morris, R. H., J. Am. Chem. Soc. 2005, 127, 1870-1882; (b) Roy, C. P.; Huff, L. A.; Barker, N. A.; Berg, M. A. G.; Merola, J. S., J. Organomet. Chem. 2006, 691, 2270-2276; (c) Kumar, P.; Singh, A. K.; Yadav, M.; Li, P.; Singh, S. K.; Xu, Q. A.; Pandey, D. S., Inorg. Chim. Acta 2011, 368, 124-131.

21. (a) Burke, K.; Perdew, J. P.; Wang, Y., Electronic Density Functional Theory: Recent Progress and New Directions; Plenum: New York, 1997; (b) Adamo, C.; Barone, V., J. Chem. Phys. 1998, 108, 664-675.

22. (a) Andrae, D.; Haussermann, U.; Dolg, M.; Stoll, H.; Preuss, H., Theor. Chim. Acta 1990, 77, 123-141; (b) Leininger, T.; Nicklass, A.; Stoll, H.; Dolg, M.; Schwerdtfeger, P., J. Chem. Phys. 1996, 105, 1052-1059.

23. (a) Zhao, Y.; Truhlar, D. G., J. Chem. Phys. 2006, 125, 194101-1-194101-18 ; (b) Zhao, Y.; Truhlar, D. G., Theor. Chem. Acc. 2008, 120, 215-241.

24. (a) Ashworth, T. V.; Singleton, J. E.; Dewaal, D. J. A.; Louw, W. J.; Singleton, E.; Vanderstok, E., Dalton Trans. 1978, 340-347; (b) Crabtree, R. H.; Quirk, J. M.; Fillebeenkhan, T.; Morris, G. E., J. Organomet. Chem. 1979, 181, 203-212; (c) Crabtree, R. H.; Quirk, J. M., J. Organomet. Chem. 1980, 199, 99-106.

25. Johnson, C. E.; Eisenberg, R., J. Am. Chem. Soc. 1985, 107, 3148-3160.

26. Rautenstrauch, V.; Hoang-Cong, X.; Churlaud, R.; Abdur-Rashid, K.; Morris, R. H., Chem.-Eur. J. 2003, 9, 4954-4967.

27. Dahlenburg, L.; Herbst, K.; Zahl, A., J. Organomet. Chem. 2000, 616, 19-28.

28. Schnider, P.; Koch, G.; Pretot, R.; Wang, G. Z.; Bohnen, F. M.; Kruger, C.; Pfaltz, A., Chem. Eur. J. 1997, 3, 887-892.

29. Blaser, H. U.; Pugin, B.; Spindler, F.; Thommen, M., Acc. Chem. Res. 2007, 40, 1240-1250.

30. Zimmer-De Iuliis, M.; Morris, R. H., J. Am. Chem. Soc. 2009, 131, 11263-11269.

31. Frisch, M. J., et al., Gaussian 09, Revision A.1; Gaussian Inc.: Wallingford, CT 2009.

32. Kulkarni, A. D.; Truhlar, D. G., J. Chem. Theory Comput. 2011, 7, 2325-2332.

33. (a) Clark, T.; Chandrasekhar, J.; Spitznagel, G. W.; Schleyer, P. V., J. Comput. Chem. 1983, 4, 294-301; (b) Lynch, B. J.; Zhao, Y.; Truhlar, D. G., J. Phys. Chem. A 2003, 107, 1384-1388. 
34. Frisch, M. J.; Pople, J. A.; Binkley, J. S., J. Chem. Phys. 1984, 80, 3265-3269.

\section{Table of Contents}

A series of iridium complexes containing a primary amine based $\mathrm{N}$-heterocyclic carbene ligand $\left(\mathrm{C}-\mathrm{NH}_{2}\right)$ were synthesized and their catalytic activity towards hydrogenation reactions was studied. A rare structure of an octahedral iridium(III) hydridochloride complex with hydride and amine donors trans to each other is reported.

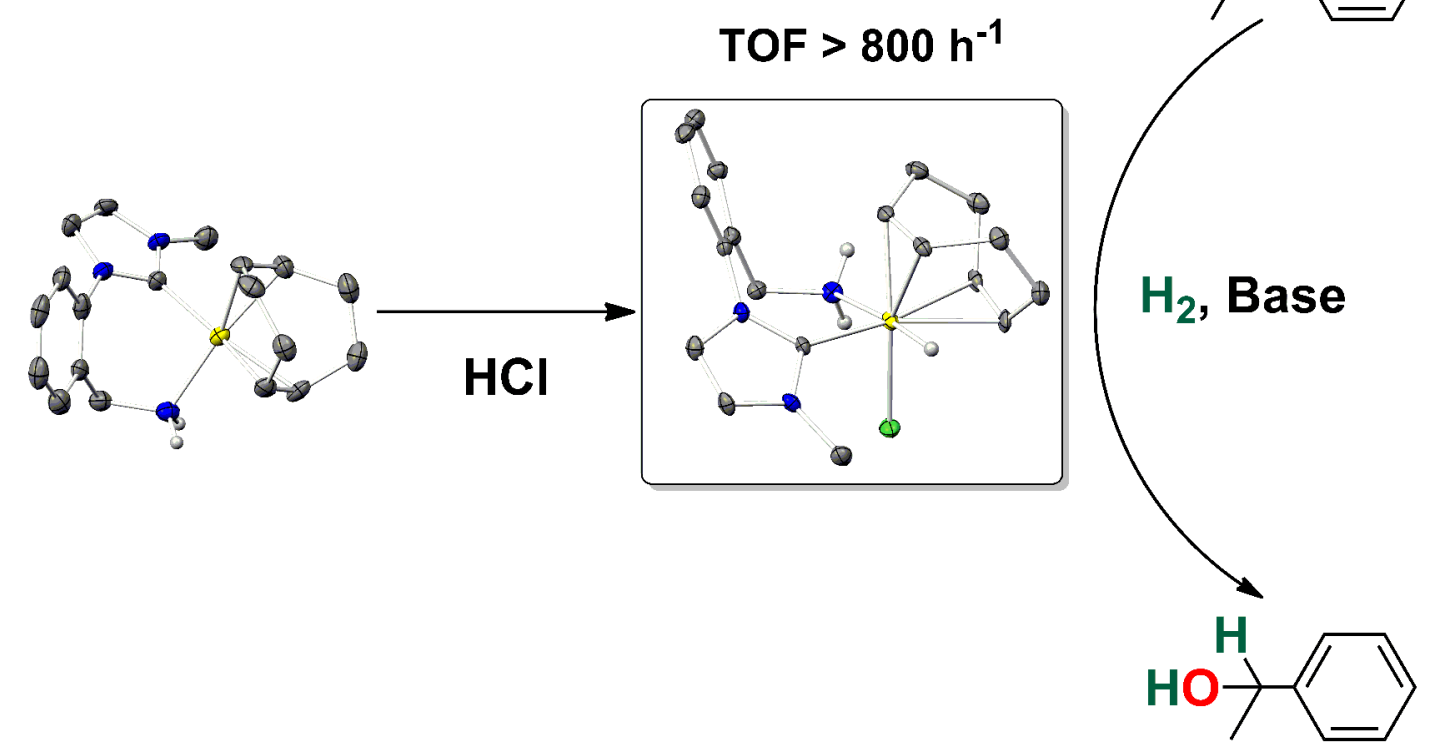

